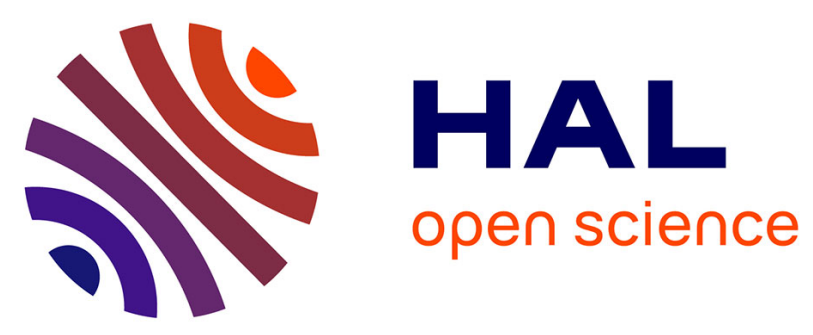

\title{
The Zanhuang Massif, the second and eastern suture zone of the Paleoproterozoic Trans-North China Orogen
}

Pierre Trap, Michel Faure, Wei Lin, Patrick Monié, Sébastien Meffre, Jérémie Melleton

\section{- To cite this version:}

Pierre Trap, Michel Faure, Wei Lin, Patrick Monié, Sébastien Meffre, et al.. The Zanhuang Massif, the second and eastern suture zone of the Paleoproterozoic Trans-North China Orogen. Precambrian Research, 2009, 172 (1-2), pp.80-98. 10.1016/j.precamres.2009.03.011 . insu-00403871

\section{HAL Id: insu-00403871 https://hal-insu.archives-ouvertes.fr/insu-00403871}

Submitted on 14 Aug 2009

HAL is a multi-disciplinary open access archive for the deposit and dissemination of scientific research documents, whether they are published or not. The documents may come from teaching and research institutions in France or abroad, or from public or private research centers.
L'archive ouverte pluridisciplinaire HAL, est destinée au dépôt et à la diffusion de documents scientifiques de niveau recherche, publiés ou non, émanant des établissements d'enseignement et de recherche français ou étrangers, des laboratoires publics ou privés. 


\title{
The Zanhuang Massif, the second and eastern suture zone of the Paleoproterozoic Trans-North China Orogen
}

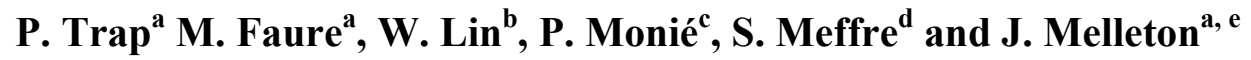 \\ ${ }^{a}$ Université d'Orléans, CNRS/INSU, Université François Rabelais - Tours Institut des \\ Sciences de la Terre d'Orléans - UMR 6113 Campus Géosciences 1A, rue de la Férollerie \\ 45071 Orléans Cedex 2, France
}

${ }^{\mathrm{b}}$ State Key Laboratory of Lithosphere Evolution, Institute of Geology and Geophysics, Chinese Academy of Sciences, Beijing 100029, China

${ }^{\mathrm{c} G e ́ o s c i e n c e s ~ M o n t p e l l i e r, ~ U M R ~ C N R S ~ 5243, ~ U n i v e r s i t e ́ ~ M o n t p e l l i e r ~ I I, ~} 34095$ Montpellier Cedex 5, France

${ }^{\mathrm{d} A R C}$ Centre of Excellence in Ore Deposits, University of Tasmania, Private Bag 79, Hobart, Tasmania 7001, Australia

${ }^{\mathrm{e}}$ Bureau de Recherche Géologiques et Minières (BRGM), BP 36009, 45060 Orléans Cedex 2, France

\begin{abstract}
This paper presents a reappraisal of the tectonic evolution of the Zanhuang Massif that lies at the eastern margin of the Trans-North China Orogen, a continent-continent collision belt that marked the amalgamation of the North China Craton in Late Paleoproterozoic. Detailed field work with focus on geometries of structures and kinematics was performed. This was completed with LA-ICP-MS U-Pb analyses on zircon, EPMA U-Th/Pb dating on monazite and ${ }^{40} \mathrm{Ar} /{ }^{39} \mathrm{Ar}$ dating on amphibole. These studies led us to propose a new three-fold lithotectonic subdivision of the massif: The Western Zanhuang Domain (WZD) made of TTG, migmatite and pink anatectic granite is correlated to the Fuping Massif that crops out to the north-west. Both areas represent a continental block, called the Fuping Block, which acquired most of its architecture around $2100 \mathrm{Ma}$ ago. The Eastern Zanhuang Domain (EZD) made of TTG and migmatite represents the western edge of an Eastern Neoarchean Block. In between, the Central Zanhuang Domain (CZD) is a NE-SW trending stack of supracrustal, gneiss and mafic magmatic rocks thrust sheets displaced toward the ESE upon the Eastern Block. The lithological features suggest that the CZD represents the remnant of an oceanic basin, called the Taihang Ocean that closed during the amalgamation of the Eastern Block and the Fuping Block around 1880-1850 Ma. In agreement with recent work done along the western margin of the belt, in the Lüliang Massif, this study documents the amalgamation of the North China Craton in response to the closure of two oceanic basins, namely the Lüliang Ocean and the Taihang Ocean. West-dipping subductions and collisions involving three distinct continental blocks, called the Western, the Fuping and the Eastern Blocks, took place around 1880$1850 \mathrm{Ma}$.
\end{abstract}

Keywords: Trans-North China Orogen; Structural analysis; North China Craton; Paleoproterozoic geodynamics; Zanhuang Massif 


\section{Introduction}

The Trans-North China Orogen has usually been described as a collisional orogen that marked the amalgamation of two main continental blocks, named the Eastern and the Western Blocks, to form the basement of the North China Craton (Fig. 1A; [Zhao et al., 1998], [Zhao et al., 2001], [Zhao et al., 2005], [Wilde et al., 2002], [Wilde and Zhao, 2005], [Guo et al., 2002], [Guo et al., 2005], [Kröner et al., 2005], [Kröner et al., 2006], [Kusky et al., 2007], [Polat et al., 2005], [Wu et al., 2005] and [Liu et al., 2006]). Three different scenarios have been proposed to account for the tectonic evolution of the belt. Some authors suggest an eastwarddirected subduction, with collision at $\sim 1.85 \mathrm{Ga}$ ([Zhao et al., 1998], [Zhao et al., 1999], [Zhao et al., 2000a], [Zhao et al., 2000b], [Zhao et al., 2001], [Zhao et al., 2002], [Zhao et al., 2004], [Wilde et al., 2002], [Kröner et al., 2005], [Kröner et al., 2006] and [Zhang et al., 2007]), other authors propose a $\sim 2.5 \mathrm{Ga}$ collision in response to a westward-directed subduction ([Kusky et al., 2007], [Kusky and Li, 2003], [Polat et al., 2005] and [Li and Kusky, 2007]). A third school of though argue for a westward-directed subduction and collision around $1.88 \mathrm{Ga}$ ([Faure et al., 2007], [Trap et al., 2007], [Trap et al., 2008] and [Trap et al., in press]). In addition to the timing of collision and subduction sense issues, important disagreements still exist when deciphering the tectonic and structural framework of the TNCO, i.e. the distinction of the discrete litho-tectonic units, structural and kinematics relationships and their tectonic significance.

Among several disconnected massifs that form the TNCO, the central positioned Hengshan, Wutaishan and Fuping massifs have been intensely studied in terms of lithology, petrology, geochemistry, geochronology, and tectonics. As a consequence, the above-mentioned models are based on works done on these three massifs ([Kröner et al., 2005], [Zhao et al., 2004], [Zhao et al., 2007], [Zhang et al., 2007], [Trap et al., 2007] and [Trap et al., 2008]). Although these studies brought important new insights, some key elements remain lacking for a complete understanding of the evolution of the belt. In particular, the tectonic relationships between the Eastern and Western Blocks were poorly documented. The understanding of the entire Trans-North China Orogen requires focusing on the structural features along its boundaries with the Eastern and Western Blocks. The Lüliangshan and Zanhuang Massifs expose these western and eastern boundaries, respectively (Fig. 1B). Recently, structural and geochronological works in the westernmost Lüliangshan Massif documented a new tectonic framework with the recognition of a suture zone, called the Trans-North China Suture ([Faure et al., 2007] and [Trap et al., in press]). The Trans-North China Suture marked the closure, around $1880 \mathrm{Ma}$, of an oceanic basin called the Lüliang Ocean. This suture constitutes the lithospheric boundary along which ophiolitic and crustal nappes are rooted whereas they thrust toward the SE over a para-autochtonous domain that crops out in the Fuping Massif near the eastern margin of the belt ([Faure et al., 2007], [Trap et al., 2007] and [Trap et al., 2008]).

The Zanhuang Massif is the easternmost outcropping part of the Trans-North China Orogen and therefore is the most promising area to investigate the tectonic relationships with the Eastern Block. Curiously, a very few papers deals with the structure of the Zanhuang Massif and its significance within the Trans-North China Orogen. Previous studies considered the Zanhuang Massif as a Mesozoic metamorphic core complex ([Ma and He, 1989] and [Niu et al., 1994]), but these models have been proved to be erroneous since the ductile structures are unconformably covered by subhorizontal sedimentary rocks of the Late-Paleoproterozoic to Mesoproterozoic Changcheng Group ([HBGMR, 1989] and [Wang et al., 2003]). The most complete and recent studies brought important new structural and ${ }^{40} \mathrm{Ar}-{ }^{39} \mathrm{Ar}$ geochronological 
insights to understand the Zanhuang Massif ([Wang et al., 2003] and [Wang et al., 2004]). These studies mainly documented the post-collisional tectonic history without discussing the place of the Zanhuang Massif with respect to the other massifs that form the Trans-North China Orogen.

In this contribution, we reappraise the lithological and structural elements of the Zanhuang Massif. Furthermore, some new LA-ICP-MS U-Pb analyses on zircon, EPMA U-Th/Pb dating on monazite and ${ }^{40} \mathrm{Ar} /{ }^{39} \mathrm{Ar}$ dating on amphibole are presented. By comparison with our previous investigations in the other massifs constitutive of the TNCO ([Faure et al., 2007], [Trap et al., 2007] and [Trap et al., 2008]) we argue that the Zanhuang Massif exposes the suture zone between the Eastern Block and the Fuping Block.

\section{Lithological units and bulk architecture of the Zanhuang Massif}

The Zanhuang Massif is a NNE trending, 40-60 km wide and $\sim 140 \mathrm{~km}$ long ArcheanPaleoproterozoic metamorphic domain that is located in the eastern segment of the TNCO (Fig. 1). No post-paleoproterozoic granite crops out in the Zanhuang massif but NNE- and NW-striking unmetamorphosed acidic and mafic dykes cut across the Archean and Paleoproterozoic rocks. ${ }^{40} \mathrm{Ar} /{ }^{39} \mathrm{Ar}$ geochronology of mafic dykes yielded plateau ages between $1765.3 \pm 1.1$ and $1780.7 \pm 0.5 \mathrm{Ma}$ (Wang et al., 2004). These dykes are covered by the LatePaleoproterozoic Changcheng group mostly made of sandstone deposited after $\sim 1700 \mathrm{Ma}$ in the whole NCC and more precisely after $1765 \mathrm{Ma}$ in the Zanhuang Massif (Figs. 1 and 7A and B; HBGMR, 1989, [Wan et al., 2003] and [Wang et al., 2004]). Elsewhere, Archean to Paleoproterozoic rocks lies beneath the Paleo-Mesozoic sedimentary cover (Fig. 1). In this study, we describe the Archean-Paleoproterozoic architecture of the Zanhuang Massif as three-fold: the Western Zanhuang Domain (WZD), the Eastern Zanhuang Domain (EZD) and the Central Zanhuang Domain (CZD; Fig. 1 and Fig. 3).

\subsection{The Western Zanhuang Domain (WZD)}

The Western Zanhuang Domain (WZD) is a $20 \mathrm{~km}$ wide and $100 \mathrm{~km}$ long area that forms the western part of the massif, within which three lithologies are distinguished. The WZD is mainly composed of trondhjemitic, tonalitic and granodioritic (TTG) rocks that experienced a partial melting episode yielding to the formation of migmatite with TTG enclaves ranging from metre to several kilometres in size. In addition, some anatectic granites form $\mathrm{N}-\mathrm{S}$ to WNW-ESE trending, 2-10 km wide and 10-15 km long, elongated plutonic bodies (Fig. 1). The anatectic granite consists of pink monzogranitic gneisses and granodioritic gneisses. The migmatite and anatectic granites are restricted to the northern part of the WZD (Fig. 1). Yet, the age of these TTG, migmatite and anatectic granites have not been constrained. These rocks, termed the 'Zanhuang Group' have been attributed to the Late Archean, around 2500$2600 \mathrm{Ma}$ (HBGMR, 1989). Also, minor quartzite, amphibole schist and marble have been recognized in the WZD (HBGMR, 1989).

Quantitative thermobarometry has not been performed in the high-grade rocks of the WZD, but temperature and pressure estimated from garnet-bearing rocks based on garnet-amphibole and garnet-biotite metamorphic equilibrium range around $550-700{ }^{\circ} \mathrm{C}$ and $5-10 \mathrm{kbar}$ (HBGMR, 1989). Furthermore, the evidence of partial melting potentially constrains the temperature higher than $700{ }^{\circ} \mathrm{C}$, as quantified northwestward, in the Fuping Massif where partial melting occurred with temperature up to $850-950{ }^{\circ} \mathrm{C}$ at a minimal pressure around 8 9 kbar (Zhao et al., 2000a). 
On the west and north, the high-grade metamorphic rocks are unconformably covered by unmetamorphosed to weakly metamorphosed clastic sedimentary rocks made up of coarse to fine-grained sandstones, conglomerates, quartzite and phyllite. These rocks, attributed to the Late Paleoproterozoic Nanshizhang Group, deposited before $1800 \mathrm{Ma}$ as they are cut by the 1700-1800 Ma old dykes (HBGMR, 1989).

\subsection{The Eastern Zanhuang Domain (EZD)}

The EZD is a $15 \mathrm{~km}$ wide and $70 \mathrm{~km}$ long area that forms the south-easternmost part of the Zanhuang Massif. Lithologies within the EZD are quite similar to those of the WZD as it consists of TTG gneiss and migmatites, leading previous authors to consider that both EZD and WZD belong to the same high-grade 'Zanhuang Group' ([HBGMR, 1989], [Niu et al., 1994] and [Wang et al., 2003]). Migmatite commonly includes stretched amphibolite lenses, as well as preserved coarse grained orthogneiss and garnet bearing tonalitic gneiss. Alike for the WZD, no recent geochronological constraints are available and the protolith ages are estimated around 2400-2600 Ma ([HBGMR, 1989] and [Wang et al., 2003]). It is worth noting that conversely to the WZD, we did not observe any pink anatectic granite. The WZD rocks experienced an amphibolite to granulite facies metamorphism but metamorphic ages and thermo-barometric constraints are still unknown. Apart from some lithological and metamorphic similarities, the structural features between the WZD and the EZD are very different (see Section 3).

\subsection{The Central Zanhuang Domain}

The CZD forms a $120 \mathrm{~km}$ long and 5-10 km wide stripe where most of sedimentary, and volcanic-sedimentary rocks of the Zanhuang Massif crops out (Fig. 1 and Fig. 3). The volcanic and volcanic-sedimentary pile is highly disrupted by several shear zones that led to the interleaving of kilometre-scale orthogneissic and migmatitic thrust slices. Due to this important deformation, the reconstruction of a single lithological log is quite difficult to settle. In the following, the main rock-types are presented in terms of litho-structural units. From west to east, five litho-tectonic units can be recognized: (i) a Quartz Schists Unit, (ii) a Volcanic-sedimentary and Carbonated Flysch Unit, (iii) a Micaschist and Paragneiss Unit, (iv) an Orthogneiss and Migmatite Unit and (v) a Marble Unit. They are globally arranged in the same order, from west to east, as the general dip is consistently westward.

(i) The Quartz Schists Unit crops out mainly in the northern part of the central zone (Fig. 1C). Good outcrops lie in the vicinity of Haozhuang village $\left(\mathrm{N} 37^{\circ} 28.583^{\prime} / \mathrm{E} 114^{\circ} 15.411^{\prime}\right)$. It consists of weakly metamorphosed clastic quartzeous chloritoschist, muscovite bearing middle to coarse grained sandstone, medium grained chlorite bearing sandstone, chlorite and muscovite bearing schist, biotite and muscovite bearing quartzite, biotite-muscovite-chlorite bearing schist. In spite of tectonic contact between each unit, some calcareous levels within the lower part of the series may define a transition zone with the underlying Volcanicsedimentary and Carbonated Flysch Unit (Fig. 2A).

\subsection{Bulk architecture of the Zanhuang Massif}

The CZD does not constitute a primary lithological succession but forms a stack of tectonically imbricated units. It is worth noting that the metamorphic grade increases from 
West to East and from top to bottom, i.e. from weakly metamorphosed muscovite quartzite and chloritoschist to highly metamorphosed marble and garnet bearing amphibolite.

We describe the CZD as a stack of metavolcanic-sedimentary rocks and magmatic rocks pinched between the WZD and the EZD and thrust over the latter toward the SE (Fig. 1 and Fig. 3). Within the CZD, each unit is bounded by ductile shear zones some of which experienced reverse and normal shearing (see Section 3). The Podi-Haozhuang shear zone is the most important tectonic contact within the Zanhuang Massif and bounds the eastern edge of the WZD that tectonically lies above the CZD. The unconformably deposited Nanshizhang group represents the highest part of the edifice whereas the EZD is the lowest one (Fig. 3).

\section{Structural analysis}

Our field survey yielded to the recognition of the following events: (i) an early pre-nappe stacking deformation $\left(\mathrm{D}_{1}\right)$; (ii) a syn-nappe stacking deformation $\left(\mathrm{D}_{2}\right.$ and $\left.\mathrm{D}_{3}\right)$; (iii) a postnappe stacking deformation $\left(\mathrm{D}_{4}\right)$. In addition, the Nanshizhang Group shows also a ductile deformation that may have developed after the $\mathrm{D}_{2}$ and before the $\mathrm{D}_{4}$ event. A summary of the structural features that define each deformation event is given in Table 1.

\subsection{The early deformation $\left(D_{1}\right)$}

The $\mathrm{D}_{1}$ deformation is mainly recorded within high-grade metamorphic rocks of the WZD, west of the Podi-Haozhuang shear zone (Fig. 1). The main $\mathrm{D}_{1}$ fabric is a pervasive foliation, termed $\mathrm{S}_{1}$, that developed within the TTG gneiss, migmatite and to a lesser extent in the pink anatectic granite. Within the TTG, the $\mathrm{S}_{1}$ foliation is marked by the gneissic layering of quartz-feldspar and ferromagnesian minerals. In migmatite, the foliation is marked by the preferred orientation of the quartz-K-feldspar rich leucosomes and the biotite-hornblende rich melanosomes that develop parallel to the gneissic layering in the paleosome. Commonly, metre-sized mafic restites are flattened and boudinaged lenses within the $\mathrm{S}_{1}$ foliation. Quartzfelspar-rich melt formed in high strain zones are concentrated in boudin neck or propagate as centimetre- to decimetre-thick dykelets that cut across the $S_{1}$ foliation, suggesting that the $D_{1}$ deformation is coeval with partial melting. The pink anatectic granite shows a weak magmatic layering that trends parallel to the $\mathrm{S}_{1}$ foliation in gneissic and migmatitic country rocks. In some places, the anatectic pink granite is isotropic whereas it is pervasively deformed along its margins with the surrounding rocks. This change in strain intensity from the core to the margin of the pink anatectic plutons is in agreement with its syntectonic origin, likely coeval with migmatization ([Teyssier and Whitney, 2002] and [Trap et al., 2008]). Metre-scale mylonitic zones parallel to $S_{1}$ that also marked the heterogeneous strain have been observed within TTG gneiss. The azimuth of $\mathrm{S}_{1}$ ranges consistently from N150E to N190E with a preferred trend around N170E (Fig. 1 and Fig. 4). $S_{1}$ is steeply dipping or vertical in the northern part of the WZD whereas shallowly dipping $\left(<45^{\circ}\right)$ in its southern counterpart. The geometry of $\mathrm{S}_{1}$ defines antiformal and synformal structures with a kilometer-scale wavelength. Despite that stereograms do not show a clear great circle girdle distribution of $S_{1}$, a nearly horizontal N170E direction can be inferred for theses antiforms and synforms (Fig. 4).

The $\mathrm{S}_{1}$ foliation holds a mineral and stretching lineation, $\mathrm{L}_{1}$ that is quite difficult to observe. $\mathrm{L}_{1}$ is defined by the preferred orientation of long-shaped minerals such as hornblende grains and elongated quartz-bearing pressure shadows around porphyroblasts. Evidence for stretching lineation also includes the elongation of biotite and quartz-feldspar aggregates that 
developed within TTG gneiss, migmatite, and the anatectic granite. The $\mathrm{L}_{1}$ is steeply plunging or vertical (Fig. 4). Rare kinematic criteria such as asymmetric K-feldspar porphyroclasts within pink granite or asymmetric quartz lenses within migmatite show either an east-directed and west-directed normal shearing. Along the hanging wall of the Podi-Haozhang shear zone, $\mathrm{D}_{1}$ structures have been largely reworked by subsequent deformation events. Some rare evidence of syn-migmatization $\mathrm{D}_{1}$ deformation exists within migmatite of the EZD and within migmatite of the Gneiss and Migmatite Unit of the CZD.

A quantitative estimation of the syn- $\mathrm{D}_{1}$ metamorphic $\mathrm{P}-\mathrm{T}$ conditions is precluded since we did not undertook the thermobarometric work and it does not exist in previous studies. Nevertheless, since $\mathrm{D}_{1}$ formed during partial melting and anatectic plutonism, it is likely that a low to moderate pressure and high temperature amphibolite to granulite facies regional metamorphism developed coevally with $\mathrm{D}_{1}$.

\subsection{The main deformation $\left(\mathrm{D}_{2}\right)$}

$\mathrm{D}_{2}$ was responsible for the dominant structural fabrics within the Zanhuang Massif, in particular in the CZD and the EZD. $\mathrm{D}_{2}$ consists of a pervasive foliation $\left(\mathrm{S}_{2}\right)$, a stretching and mineral lineation $\left(\mathrm{L}_{2}\right)$ and folds $\left(\mathrm{F}_{2}\right) . \mathrm{S}_{2}$ is characterized by the preferred orientation of biotite, amphibole, muscovite and elongated quartz grains. $\mathrm{S}_{2}$ is also well defined by centimetre to several metre scale mylonitic shear zones, among which some form the litho-tectonic boundaries between units of the CZD. $\mathrm{S}_{2}$ strikes consistently N40-60E and is weakly dipping toward the NW or even flat lying, in particular in the EZD and the southern CZD (Fig. 1 and Fig. 4). $S_{2}$ becomes steeper in the western part of the northern CZD (Fig. 1, Fig. 3 and Fig. 4).

The $\mathrm{L}_{2}$ lineation is marked by the preferred orientation of amphibole, pressure shadows around garnet porphyroblasts, elongated biotite aggregates (Fig. 5A). In addition, some small scale tight or even intrafolial folds $\left(\mathrm{F}_{2}\right)$ with axes parallel to $\mathrm{L}_{2}$ represent a-type folds developed during $\mathrm{D}_{2}$ (Fig. 5B). Within the Gneiss and Migmatite Unit of the CZD such a-type folds rework the $S_{1}$ migmatitic foliation. Within the volcano-sedimentary rocks, microfolds around epidosite lenses have a N140-130E axes that are parallel to $\mathrm{L}_{2}$. The maximum stretching $\mathrm{X}$ axis of the finite strain ellipsoid is also represented by prolate shaped pillows. $\mathrm{L}_{2}$ trends from N120E to N160E with a maximum around N140E and a plunge towards the NW (Fig. 4).

Along the $\mathrm{L}_{2}$ lineation, numerous top-to-the SE kinematic indicators are observed. The commonest criteria consist of $\sigma$-type porphyroclast systems, S-C fabrics, sigmoidal shaped competent quartz layers within marbles or drag folds along mylonitized gneiss (Fig. 5C-F). West of the marble unit of the CZD, plurimetric scale mafic dykes intruding in the migmatitic gneiss have been highly sheared and boudinaged and now crop out as metre scale asymmetric lenses showing a clear top-to-the SE sense of shear (Fig. 5G). The general top-to-the SE displacement of metamorphic rocks is accommodated by metre to decametre-scale mylonitic shear zones along which $\mathrm{D}_{2}$ fabric is pronounced. The main shear zones commonly lies along the lithological boundaries, and represent ductile thrust faults responsible for the tectonic stacking of the different litho-tectonic units described in the central zone (cf. Section 2, Fig. 3). In particular, the Podi-Haozhuang shear zone, that separates the WZD and the CZD, is the most important thrust fault of the massif since it is responsible for the juxtaposition of the WZD high-grade rocks in the hanging wall against low-grade metasedimentary rocks of the CZD in the footwall. In addition, several second order reverse ductile shear zones account for the duplication of the units in the Central Zanhuang Domain. It is worth noting that some of 
these $\mathrm{D}_{2}$ shear zones are also reworked during the $\mathrm{D}_{4}$ deformation (see Section 3.3). In the western vicinity of the Podi-Haozhuang shear zone, migmatite and TTG of the WZD experienced the $\mathrm{D}_{2}$ deformation with the development of a $\mathrm{N} 160 \mathrm{E}$ trending $\mathrm{L}_{2}$ mineral lineation. $\mathrm{S}_{2}, \mathrm{~L}_{2}$ and top-to-the $\mathrm{SE}$ shearing that characterized the $\mathrm{D}_{2}$ event developed in the entire CZD and the EZD. Therefore, the greenschist facies to amphibolite facies conditions metamorphism described in Section $\underline{2}$ is related to $\mathrm{D}_{2}$.

\subsection{The top-to-the SE folding $\left(D_{3}\right)$}

$\mathrm{S}_{2}$ and $\mathrm{L}_{2}$ are deformed by $\mathrm{F}_{3}$ folds that range from a few metres to a few hundreds of metres in wavelength. These N50E trending folds are commonly overturned toward the SE as evidenced by their axial planes dipping toward the NW (Fig. 4). Hinges of $\mathrm{F}_{3}$ folds are generally horizontal. This top-to-the SE folding is observed in the Central Zanhuang Domain.

\subsection{The late deformation $\left(D_{4}\right)$}

In contrast to $\mathrm{D}_{2}$, which is pervasive within the CZD, EZD and easternmost part of the WZD, the $\mathrm{D}_{4}$ deformation is concentrated only along decimetre to metre thick mylonitic shear zones developed preferentially within softer lithologies (Fig. 6A). $\mathrm{S}_{4}$ commonly lies parallel to $\mathrm{S}_{2}$ with a N40-60E strike and a moderate dip toward the NW. $\mathrm{S}_{4}$ surface contains a $\mathrm{L}_{4}$ stretching lineation marked by the preferred orientation of quartz-feldspar aggregates, epidote, alignment of fine-grained muscovite or chlorite grains and quartz, pressure shadows around porphyroclasts. The strike and plunge of $\mathrm{L}_{4}$ are consistent at $\mathrm{N} 110-120 \mathrm{E}$ and $20-50^{\circ}$ toward the WNW, respectively (Fig. 4). Along the local $\mathrm{D}_{4}$ shear zones, kinematic indicators, such as centimetre spaced shear bands, chlorite and mica fishes, $\sigma$-type porphyroclast systems show a top-to-the $\mathrm{W}$ displacement indicating a normal shearing (Fig. 6A and B). Within epidosite lenses of the 'Volcanic and Carbonated Flysch Unit', quartz-filled en-echelon tension gashes are in agreement with the top-to-the $\mathrm{W}$ normal shearing. Centimetre- to decimetre-scale drag folds overturned to the west are in agreement with a normal shearing movement during $\mathrm{D}_{4}$ (Fig. 6C). An overprinting relationship of $\mathrm{S}_{4}$ centimetre spaced normal-shear zones reworking the synfolial $\mathrm{D}_{2}$ folds can be observed and thus attests for relative timing sequence. The metamorphic minerals (quartz, chlorite, epidote, muscovite) observed along $\mathrm{L}_{4}$ indicate that $\mathrm{D}_{4}$ developed coevally with a greenschist facies metamorphism.

\subsection{The deformation within the Nanshizhang Group}

The Nanshizhang group rocks are nearly unmetamorphosed but show a ductile deformation characterized by slaty cleavage, stretching lineation, and development of folds. A slaty cleavage mainly develops within the mudstone layers whereas it is only a fracture cleavage within the red-brown sandstone (Fig. 7C). Within conglomerate layers, the slaty cleavage is defined by the preferred orientation of flattened pebbles deformed by pressure-solution. A weakly developed stretching lineation defined by elongated black-greenish mudstone aggregates or elongated pebbles has been observed in a few outcrops (Fig. 7D). This lineation plunges highly toward the WNW (Fig. 4).

Kilometre-scale open folds are demonstrated by the attitude of the bedding. In the northern part of the WZD, the orientation of the bedding ranges from N165E60E to N205E45W, whereas in the western part of the WZD, the bedding strikes consistently N5-20E and dips steeply or moderately mainly toward the west. The geometric relationships between the bedding and the slaty cleavage indicate that the kilometer-scale recumbent folds are east 
verging. This is corroborated by the top-to-the east overturned metre scale and microfolds associated with an axial planar slaty cleavage. The place of the deformation in the Nanshizhang Group with respect to the $\mathrm{D}_{1}-\mathrm{D}_{4}$ events described in the metamorphic rocks will be discussed in Section $\underline{5}$.

\section{Geochronological constrains}

Existing geochronological data within the Zanhuang Massif are very sparse. Most of geochronological insights are $\mathrm{K} / \mathrm{Ar}$ and ${ }^{40} \mathrm{Ar} /{ }^{39} \mathrm{Ar}$ ages that constrain the late normal faulting and global uplift, around 1826 and $1650 \mathrm{Ma}$, respectively ([HBGMR, 1989], [Wang et al., 2003] and [Wang et al., 2004]). In order to bring new geochronological constrains of the above described deformation events, five samples: FP390, FP395, FP396, FP400, and FP403 were studied using different methods, such as U-Pb LA-ICP-MS on zircon, U-Th/Pb EPM chemical dating on monazite and ${ }^{40} \mathrm{Ar} /{ }^{39} \mathrm{Ar}$ dating on amphibole. Sample location is shown in Fig. 1C.

\subsection{Zircon LA-ICP-MS U-Pb analyses}

\subsection{1. $U-P b$ method}

The rocks were crushed in a ring mill and sieved $(400 \mu \mathrm{m})$. Non-magnetic and slightly magnetic heavy minerals were separated from the $<400 \mu \mathrm{m}$ fraction. Large zircon grains were then picked from the heavy mineral separate and mounted in epoxy. The samples were analyzed using a Hewlet Packard 4500 quadrupole ICPMS and a New Wave UP $213 \mathrm{~nm}$ laser at CODES, University of Tasmania. Ablation was performed in a custom designed chamber in a He atmosphere using a laser pulse rate of $5 \mathrm{~Hz}$ on a beam $30 \mu \mathrm{m}$ in size delivering about $13 \mathrm{~mJ} \mathrm{~cm}^{-2}$. A total of 11 masses were analysed ( $\left.\mathrm{Zr}, \mathrm{Hf}, \mathrm{Nd}, \mathrm{Hg}, \mathrm{Pb}, \mathrm{Th}, \mathrm{U}\right)$ with longer counting time on the $\mathrm{Pb}$ and $\mathrm{U}$ isotopes. Each analysis began with a $30 \mathrm{~s}$ gas blank followed by $30 \mathrm{~s}$ with the laser switched on. Mass bias, down hole fractionation and instrumental drift were corrected by analysing 4 crystals of the Temora international zircon standard ([Black et al., 2003] and [Black et al., 2004]) for every 12 unknown zircons. The correction factors were then checked using 91500 international zircon standard (Wiedenbeck et al., 1995) analysed twice for every 12 unknown zircons. Data reduction was performed using the methods outlined by Black et al. (2004). Weighted averages and Concordia plots were calculated using the isoplot software of Ludwig (2004).

\subsection{2. $U-P b$ zircon results}

$\mathrm{U} / \mathrm{Pb}$ analytical results are summarized in Table 2. Isochron diagrams are shown in Fig. 8. Sample FP390 is a biotite and amphibole bearing gneiss collected in the Gneiss and Migmatite Unit, SE of Shicao (Fig. 1). In the outcrop, $\mathrm{S}_{2}$ trends N30E and dips $40^{\circ}$ toward the west. $\mathrm{L}_{2}$ is well expressed and trends N135E and a top-to the SE sense of shear is observed. Ten zircon analyses from sample FP390 defined a well constrained Discordia intersecting Concordia at $626 \pm 45$ and $2606 \pm 60 \mathrm{Ma}$ (Fig. 8A). The upper intercept age is interpreted as the crystallization age of the granitic protolith. The lower intercept age at $626 \pm 45 \mathrm{Ma}$ is difficult to relate to a known tectonic event that affected the NCC during the Neoproterozoic period.

Sample FP395 is a migmatitic leucosome from the EZD, east of Chenjitou (Fig. 1). In the outcrop, $\mathrm{S}_{2}$ trends N50E and dips $40^{\circ}$ toward the NW, $\mathrm{L}_{2}$ trends N130E. Zircons analyses plot 
along two line trends. The first one defines two Concordia intercepts at $207 \pm 240$ and $2509 \pm 80 \mathrm{Ma}$ (Fig. 8B). The age of $2509 \pm 80 \mathrm{Ma}$ is interpreted as an inherited crystallization age of the protolith of the migmatite. The second isochron, made of four analyses, show a lower intercept at $187 \pm 34 \mathrm{Ma}$ and an upper intercept at $2175 \pm 32 \mathrm{Ma}$. This last age can be interpreted as the crystallization age of the anatectic melt produced during migmatization. The lower intercepts at $187 \pm 34$ and $207 \pm 240 \mathrm{Ma}$ have no geological significance except the possible Mesozoic Yanshanian reactivation (e.g. [Davis et al., 2001] and [Zheng et al., 1996]) but this tectonothermal event is quite far north from the Zanhuang Massif.

\subsection{Monazite chemical $\mathrm{U}-\mathrm{Th}-\mathrm{Pb}$ dating}

\subsection{1. $\mathrm{U}-\mathrm{Th} / \mathrm{Pb}$ method}

Monazite grains were analyzed in situ directly in the thin section. The internal structure of monazite and textural relationship between monazites and the principal minerals of the assemblage were investigated using BSE images. EPM analyses were performed using a Cameca SX 50 electron probe microanalyser equipped with five wavelength-dispersive spectrometres using an acceleration voltage of $20 \mathrm{kV}$ and a beam current of $100 \mathrm{nA}$, cooperated by the BRGM and ISTO in Orléans, France. Counting times (peak + background) were $240 \mathrm{~s}$ for $\mathrm{Pb}, 200 \mathrm{~s}$ for $\mathrm{U}$, and $40 \mathrm{~s}$ for all other elements. The analytical and age calculation procedures follow those described in Cocherie et al. (1998) and Cocherie and Albarede (2001).

\subsection{2. $U-T h / P b E P M$ result}

$\mathrm{U}-\mathrm{Th} / \mathrm{Pb}$ electron probe microanalyses were performed on the rock FP400 that was sampled within the Micaschist and Gneiss Unit of the CZD, east of the Podi-Haozhuang shear zone (see Fig. 1 for location). Sample FP400 is a muscovite + biotite + q uartz + feldspar + garnet \pm chlorite micaschist coming from a $\mathrm{D}_{4}$ normal shear zone. The planar fabric is a $\mathrm{S}_{4}$ foliation associated to a top-to-the-West normal-shearing indicated by asymmetric quartz pressure shadows around porhyroclasts. Back-scattered electron images reveal that monazite grains show a preferred orientation along the $S_{4}$ foliation together with matrix minerals. Monazite grains are located in a matrix quartz + muscovite + biotite and range in size from 50 to $200 \mu \mathrm{m}$ (Fig. 9A and B). Grains are prismatic with a long axis parallel to the $\mathrm{S}_{4}$ foliation. Monazite grains are not chemically zoned. $\mathrm{U}-\mathrm{Th} / \mathrm{Pb}$ analytical results are summarized in Table 3. They show a large range in $\mathrm{Th} / \mathrm{U}$ ratio at $9.4 \pm 8.8$ (S.D.) and thus the chemical composition of monazite grains is favourable for using the $\mathrm{Th} / \mathrm{Pb}$ vs. $\mathrm{U} / \mathrm{Pb}$ diagram (Cocherie and Albarede, 2001). Indeed, the data spread widely in the $\mathrm{Th} / \mathrm{Pb}$ versus $\mathrm{U} / \mathrm{Pb}$ diagram (Fig. 9C). The calculated MSWD of 0.95 makes the 99 data points statically in agreement with a single age. Moreover, the intercept ages (U-Pb age at $1781+71 /-75 \mathrm{Ma}$ and $\mathrm{Th} / \mathrm{Pb}$ age at $1834+35 /-34 \mathrm{Ma}$ ) are within error and the regression line is close to the theoretical isochron. A mean age of $1824 \pm 6 \mathrm{Ma}$ was calculated at the centroid of the population (Fig. 9C).

\section{3. ${ }^{40} \mathrm{Ar} /{ }^{39} \mathrm{Ar}$ on amphiboles}

\subsection{1. ${ }^{40} \mathrm{Ar}{ }^{39} \mathrm{Ar}$ Method}

${ }^{40} \mathrm{Ar} /{ }^{39} \mathrm{Ar}$ dating was performed at Université of Montpellier II, France. The analytical procedure for laser probe dating is similar to that fully described by Dalrymple (1989). It consists of a continuous $6 \mathrm{~W}$ argon-ion laser connected to a MAP 215-50 mass spectrometre. 
Irradiation of two amphibole grains $(0.5 \mathrm{~mm}$ in diametre) was performed with several $\mathrm{MMHb}$ monitor grains (Samson and Alexander, 1987) in the McMaster nuclear reactor (Canada) for $70 \mathrm{~h}$. After irradiation, the grains were placed within a low-volume, high-vacuum extraction line and heated with a continuous $\mathrm{CO}_{2}$ laser beam. The age determination required approximately $20 \mathrm{mn}$ for lasering, gas cleaning and data acquisition. Blanks, monitored every two or three experiments, were about $6 \times 10^{-17}, 5 \times 10^{-19}, 1.5 \times 10^{-18}, 1 \times 10^{-17}$ and $3 \times 10^{-18}$ mol for masses 40,39, 38, 37 and 36, respectively. Additional details concerning our experimental procedure are given in (Monié et al., 1994) and (Monié et al., 1997).

\subsection{2. ${ }^{40} \mathrm{Ar} /{ }^{39} \mathrm{Ar}$ results}

Analytical results are listed in Table 4 and age diagrams are presented in Fig. 10. Analyses were performed on two amphibole grains from the sample FP396 and FP403. The Sample FP396 is a garnet bearing amphibolite that crops out as a metre thick layer along the boundary between the Marble Unit and the Gneiss and Migmatite Unit of the CZD (Fig. 1C). At sample location, $\mathrm{S}_{2}$ trends N50E and dips shallowly toward the west. Amphibole crystallization is coeval with the $\mathrm{D}_{2}$ deformation. Sample FP403 is a migmatitic orthogneiss with a well developed $\mathrm{S}_{2}$ mylonitic fabric that crops out in the south-eastern part of the EZD near Longmen village (Fig. 1C). $\mathrm{S}_{2}$ trends N80E and dips $40^{\circ}$ toward the north. Amphibole from sample FP396 gave a well-defined plateau age at $1802 \pm 12$ Ma for $98 \%$ of ${ }^{39}$ Ar released (Fig. 10A). Similarly, amphibole from sample FP403 yields a plateau age at $1801 \pm 12 \mathrm{Ma}$ defined for $80 \%$ of ${ }^{39}$ Ar released (Fig. 10B).

Since dated amphibole grains crystallized during the $\mathrm{D}_{2}$ deformation, the obtained ${ }^{40} \mathrm{Ar} /{ }^{39} \mathrm{Ar}$ ages would represent the timing of the $\mathrm{D}_{2}$ event. However, this is not in agreement with the monazite EPMA age of the $\mathrm{D}_{4}$ event which is determined at $1824 \mathrm{Ma}$. Thus we interpret the $1801 \pm 12$ and $1802 \pm 12 \mathrm{Ma}{ }^{40} \mathrm{Ar} /{ }^{39} \mathrm{Ar}$ ages as those of the cooling of the EZD below the $550{ }^{\circ} \mathrm{C}$ which correspond to the closure temperature of amphibole (Spear, 1993). These young dates might represent the exhumation of the thickened crust, during post-collisional isostatic recovery.

\section{Discussion}

\subsection{Lithological and tectonic significance of the Central Zanhuang Domain}

In the most recent published tectonic map of the Zanhuang Massif, the middle positioned stripe of supracrustal rocks, which we defined here as the Central Zanhuang Domain, is considered as the equivalent of the Nanshizang Group rocks that unconformably cover the Archean basement of the Western Zanhuang Domain ([Wang et al., 2003] and [Wang et al., 2004]). However, the metamorphosed and ductilely deformed CZD cannot be compared to the unmetamorphozed sedimentary rocks that crop out along the margin of the massif. The CZD and Nanshizhang Group greatly differ in lithological, metamorphic and structural features. The CZD experienced the $\mathrm{D}_{2}$ deformation that is responsible for the superposition of tectonic slices overthrust toward the SE. This nappe stacking geometry is absent in the Nanshizhang Group that consists of a terrigeneous sedimentary series that mainly experienced kilometrescale folding (the tectonic significance of the Nanshizang group is discussed in detail further).

The sedimentary and volcanic rocks that compose the western part of the Central Zanhuang Domain in the Quartz Schists Unit and the Volcano-sedimentary and Carbonated Flysch Unit might have deposited in a deep marine environment. Furthermore, the epidosites represents 
epidote and siliceous rocks that result from seafloor hydrothermal alteration of basalt in a mid-oceanic ridge environment as commonly identified within some ophiolitic complexes (e.g. Polat et al., 2007). The easternmost part of the Central Zanhuang Domain is made of marble that we interpret as platform sedimentary rocks deposited on the western margin of the Eastern Zanhuang Domain. This sedimentary setting interpretation is in agreement with that of Kusky and Li (2003) who first suggested that rocks within the Zanhuang Massif represent a passive continental margin thrust to the east upon the Eastern Block during the Archean at

$2.5 \mathrm{Ga}$. However, our geochronological results (Section 5) do not support the Archean age of the tectonics.

Therefore, we propose that the Central Zanhuang Domain is a stack of nappes among which some rock-types derived from an oceanic basin and a carbonated shelf environment. Although the absence of typical rocks, such as sheeted dykes is generally not consistent with the classical ophiolitic section (e.g., Oman), rocks of the CZD were previously interpreted as ophiolitic ([Kusky et al., 2007] and [Li and Kusky, 2007]). A simple tentative paleogeographic reconstruction would be to consider that the WZD and EZD represent two continental blocks separated by an oceanic domain, the CZD. During subsequent collision, the oceanic series have been subsequently deformed and imbricated as kilometer-scale slices bounded by east-verging ductile thrusts. The western EZD basement, upon which a part of the metavolcanic and sedimentary rocks deposited was also involved in the east-directed $\mathrm{D}_{2}$ thrusting as slices of Archean gneiss and migmatite are tectonically intercalated within the sedimentary units. The western limit of the CZD is the Podi Haozhuang shear zone that can be interpreted as a suture zone between the EZD and WZD. The existence of such a suture zone along the eastern margin of the Trans-North China Orogen has been suggested by Faure et al. (2007), which they called the Taihangshan Suture that we documented here within the Zanhuang Massif. It resulted from the closure of the Taihang Ocean (Faure et al., 2007) that once separated two continental domains, i.e., the Western and Eastern Zanhuang domains. The structural framework of the Zanhuang Massif with metamorphic nappes that thrust toward the SE suggests that the collision occurred after a westward-directed subduction of the EZD beneath the WZD.

\subsection{Further evidence, at depth, for the existence of the Taihangshan Suture}

Wang et al. (2006) conducted a petrological and geochemical work on ca. $125 \mathrm{Ma}$ old gabbroic rocks emplaced $70 \mathrm{~km}$ south of the Zanhuang Massif (Fig. 11). The geochemistry of these early Cretaceous gabbroic rocks shows that they originated from a refractory pyroxenitic veined-plus-peridotite source previously modified by a $\mathrm{SiO}_{2}$-rich melt that may have been derived from paleoproterozoic subducted crustal materials (Wang et al., 2006). Despite that the location of the source at depth remains unknown, this assumption of a paleosubduction-related lithospheric mantle beneath the Zanhuang Massif agrees well with the surface observations provided in this study.

Zheng et al. (2006) performed on-shore seismic investigations on the eastern part of the North China Craton and obtained a lithospheric scale profile that goes from the eastern Bohai Bay basin in the SE to the northern Hengshan Massif in the NW, passing about $100 \mathrm{~km}$ northeast of the Zanhuang massif (Fig. 11). The shift in the lithospheric interfaces such as those between upper and middle crust or between middle and lower crust is clearly imaged along this seismic line (Fig. 11C). The geometry of the offset of the seismic velocity layers in the crust is in agreement with an east-directed thrust fault that could be related to a north-west- 
directed subduction. It is worth to note that this profile shows the present-day lithospheric structure beneath this segment of the NCC. Consequently, conversely to these crustal discontinuities that reflect the inherited paleoproterozoic structure, the Moho geometry results of the Phanerozoic evolution of the NCC. Indeed, the Archean and Paleoproterozoic lithospheric mantle beneath the North China Craton has been partially reworked since the Ordovician due to tectonic and thermal mechanisms, such as lithospheric delamination (Gao et al., 2002), thermal erosion of the lithosphere ([Griffin et al., 1998], [Wu et al., 2003] and $[\mathrm{Xu}, 2007])$, effect of mantle plume (e.g. Flower et al., 1998) or extensional tectonics (e.g., [Lin and Wang, 2006], [Liu et al., 2004] and [Zheng et al., 2001]).

\subsection{Structure and deformation events in the Zanhuang Massif and correlation with other massifs of the Trans-North China Orogen}

In previous studies, the TNCO was commonly subdivided into (i) low-grade granitegreenstone areas that include the Zanhuang, Lüliang and Wutaishan Massifs and (ii) highgrade areas represented by the Fuping, Henghsan, and Hua'ian Massifs ([fig11] and [Zhao et al., 2000a]). However, the present situation of these massifs results of the Cenozoic history of the North China Craton. Even if some massifs can be distinguished from others by their metamorphic grade, it is more reliable for a general understanding of the TNCO to distinguish several litho-tectono-metamorphic units that can be correlated from one to another massif. These litho-tectono-metamorphic units that are recognized at a larger scale, whatever the massifs, underwent similar metamorphic conditions and show the same structural features (e.g. [Faure et al., 2007], [Trap et al., 2007], [Trap et al., 2008] and [Trap et al., in press]).

\subsubsection{The tectonic significance of the WZD and $D_{1}$ event}

In the Zanhuang Massif, the WZD shows a peculiar structure characterized by N170E trending domes made of migmatite and pink anatectic granites developed during $\mathrm{D}_{1}$. This $\mathrm{D}_{1}$ deformation occurred during partial melting and anatectic plutonism. Migmatite is not restricted to the WZD but occurs within the CZD as a tectonic slice called the Gneiss and Migmatite Unit as well as within the EZD. The migmatization was estimated at $2175 \mathrm{Ma}$ by $\mathrm{U}-\mathrm{Pb}$ analyses. Therefore the structure of the WZD with $\mathrm{S}_{1}, \mathrm{~L}_{1}$ may have developed during this period.

$20 \mathrm{~km}$ north-westward from the WZD, the Fuping Massif shows quite similar geological structural features. The Fuping Massif consist of TTG gneiss and supracrustal rocks that crop out in synforms whereas foliated migmatite coincides with E-W trending elliptical domes, the core of which is occupied by diatexite and anatectic pink granites (Fig. 12; Trap et al., 2008). The architecture of the Fuping massif resulted from a single tectonic event responsible for the development of a dome-and-basin structure coeval with crustal melting giving rise to migmatite and gneissic granites at $\sim 2.1$ Ga (Trap et al., 2008). Thus, in agreement with a previous correlation ([Zhao et al., 2000a] and [Zhao et al., 2001]), the WZD can be linked to the Fuping Massif. Within the Trans-North China Orogen framework, the Fuping Massif and the WZD represent the para-autochthonous domain upon which several nappes thrust over (Fig. 12). This para-autochthonous domain is interpreted as the outcropping part of an intermediate continental block, called the Fuping Block, located between the Eastern and the Western Block ([Faure et al., 2007], [Trap et al., 2008] and [Trap et al., in press]). 


\subsubsection{Nappe stacking during the $\mathrm{D}_{2}$ event}

The $\mathrm{D}_{2}$ tectonic event is the most important one as it is responsible for the bulk architecture of the Zanhuang Massif. In agreement with (Wang et al., 2003) and (Wang et al., 2004), the deformation fabric, characterized by a NW-SE trending lineation and a top-to-the SE shearing, is due to the synmetamorphic thrusting and crustal thickening driven by the collision of the EZD (i.e. the Western Block) and the WZD (i.e. the Fuping Block). The $\mathrm{D}_{2}$ event is responsible for the stack of metamorphic rocks that constitutes the Central Zanhuang Domain. Within this tectonic pile, the metamorphic conditions increase from top to bottom. In this tectonic scheme, the $\mathrm{F}_{3}$ folds, overturned toward the $\mathrm{SE}$, are interpreted as a late- $\mathrm{D}_{2}$ deformation.

Our geochronological results do not allow us to constrain accurately the timing of the $\mathrm{D}_{2}$ event. However, the $\mathrm{D}_{2}$ event is older than $\mathrm{D}_{4}$ the age of which is determined around $1824 \mathrm{Ma}$ by monazite $\mathrm{U}-\mathrm{Th} / \mathrm{Pb}$ EPMA dating. This conclusion is in agreement with Wang et al. (2003) that suggest that the top-to-the SE thrusting developed around 1870-1826 Ma by comparison with westernmost Massifs. Indeed, in the nearby Wutaishan massif, similar top-to-the SE thrusting and nappe stacking was reliably constrained around 1870-1890 Ma ([Faure et al., 2007] and [Trap et al., 2007]). Thus, by comparison with the surrounding areas, we suggest that nappe stacking in the Zanhuang Massif occurred around $1880 \mathrm{Ma}$.

\subsubsection{The $\mathrm{D}_{4}$ normal-shearing}

The main tectonic contact, the Podi-Haozhuang shear zone, is reworked as a normal fault developed at ductile-brittle transition, lately in the tectonic evolution of the Zanhuang Massif. Wang et al. (2003) suggested that post-collisional collapse and exhumation of the thickened crust was responsible for divergent extensional ductile shearing represented by westward and eastward dipping normal faults to the western and eastern margins of the Zanhuang Massif, respectively, developed at around 1689-1633 Ma. According to the same authors, extensional shearing involved Mesoproterozoic rocks of the Chancheng Group. During our field survey, we did not observed such normal faults at the base of the Changcheng Group rocks that unconformably cover the weakly deformed and metamorphosed coarse grain sandstone of the Late-Paleoproterozoic Nanshizhang Group rocks (Fig. 7B). Moreover, along the eastern limit of the Nanshizhang Group, only minor layer slips and west-verging drag folds nearby the contact between WZD migmatites and overlying sandstones of the Nanshizhang Group might suggest that the primary unconformable contact has been reworked. Along the eastern margin of the Zanhuang Massif, an eastward normal ductile fault is not in agreement with the foliation trajectories in the EZD migmatite and gneiss that are always flat lying or shallowly dipping toward the west. The $\mathrm{D}_{4}$ extensional event is dated at $1824 \mathrm{Ma}$ by monazite $\mathrm{U}-\mathrm{Th} / \mathrm{Pb}$ EPMA dating (this study). This age is consistent with ${ }^{40} \mathrm{Ar} /{ }^{39} \mathrm{Ar}$ results of Wang et al. (2003) that suggest a 1826-1793 Ma age for the post-collisional extensional tectonics. The $\mathrm{D}_{4}$ extensional event does not appear to have significantly altered the primary architecture of the Zanhuang Massif formed after the $\mathrm{D}_{2}$ event.

\subsubsection{The significance of the Nanshizhang Group}

The sedimentary rocks of the Nanshizhang Group crop out in the north-western part of the Zanhuang Massif. These terrigeneous rocks are similar to those described in the south-eastern part of the Fuping massif, and ascribed to the Late-Paleoproterozoic Gantaohe Group ([fig12], [HBGMR, 1989] and [Trap et al., 2008]). There, it consists of weakly metamorphosed 
phyllite, quartzite, sandstone, conglomerate and dolomite ([HBGMR, 1989] and [Trap et al., 2008]). Therefore it is tempting to correlate the sedimentary rocks of the Nanshizhang and Gantaohe Groups. Furthermore, these unmetamorphosed sedimentary rocks, together with the Hutuo Group, in the Wutaishan Massif, compose the Hutuo Supergroup that represents molassic sediments ([fig12], [HBGMR, 1989], [Faure et al., 2007] and [Trap et al., 2008]).

Direct stratigraphic ages on the sedimentary rocks of the Nanshizhang Group are lacking. However, previous tectonic studies in the Wutaishan area suggest that these sedimentary rocks deposited unconformably after $2100 \mathrm{Ma}$ on the para-autochthonous domain and before $1.7 \mathrm{Ga}$ which is the age of the overlying Changcheng Group. The weakly metamorphosed Nanshizhang sedimentary rocks experienced a ductile deformation whose structural features are quite similar to those of the $\mathrm{D}_{2}$ deformation; in particular the top-to-the SE displacement of the $\mathrm{D}_{3}$ event can be equivalent to the synschistose folds of the Nanshizhang rocks. Thus, the Nanshizhang Group rocks deposited after the syn-metamorphic $\mathrm{D}_{2}$ deformation but before the $\mathrm{D}_{3}$ one, characterized by southeastward verging folds. Unfortunately, overprinting evidence does not allow us to settle the timing of the deformation of the Nanshizhang rocks with respect to the $\mathrm{D}_{2}$ and $\mathrm{D}_{3}$ events described in the Zanhuang Massif.

\subsection{Global structure of the Trans-North China Orogen}

As mentioned above in Section 1 , the basement of the North China Craton is considered as the result of the collision between the Eastern and Western Blocks; responsible for the 100 $300 \mathrm{~km}$ wide and $\sim 1200 \mathrm{~km}$ long Trans-North China Orogen (Fig. 1A; [Zhao et al., 1998], [Zhao et al., 2001], [Zhao et al., 2005], [Zhao et al., 2007], [Wilde et al., 2002], [Wilde and Zhao, 2005], [Guo et al., 2002], [Guo et al., 2005], [Kusky and Li, 2003], [Kröner et al., 2005], [Kröner et al., 2006], [Polat et al., 2005], [Wu et al., 2005], [Liu et al., 2006], [Li and Kusky, 2007] and [Kusky et al., 2007]). Previous geodynamic models of the evolution of the Trans-North China Orogen never describe or even accurately define any suture zone in the field ([Kusky and Li, 2003], [Zhao et al., 2005], [Kröner et al., 2005], [Zhang et al., 2007] and [Li and Kusky, 2007], Kusky et al., 2007). Instead, the TNCO is considered to be bounded from the Eastern and Western Blocks by the Xingyang-Kaifeng-Shijiazhuang-Jianping Fault and the Huashan-Lishi-Datong-Duolun Fault, respectively (Fig. 11). These faults may represent cryptic Late Archean to Paleoproterozoic tectonic boundaries that were reactivated during the Mesozoic ([fig11], [Zhao et al., 2000a] and [Zhao et al., 2007]).

Recently, a first suture zone has been recognized in the western part of the Lüliang Massif. This region corresponds to the root zone of the metamorphic nappes that compose the upper part of the Wutaishan Massif ([fig12], [Faure et al., 2007], [Trap et al., 2007] and [Trap et al., in press]). In this contribution, we document a second suture zone, located along the PodiHaozhuang shear zone, between the Fuping Block and the Eastern Block. At the scale of the North China Craton, the Fuping Block is a microcontinent located between the Western Block and the Eastern Block ([Faure et al., 2007], [Trap et al., 2007] and [Trap et al., 2008]). The Trans-North China Orogen thus resulted from the closure of two oceanic basins, the Lüliang and Taihang Oceans, accommodated by two westward-directed subductions. The subduction of the Fuping Block below the Western Block and the subduction of the Eastern Block below the Fuping Block were responsible for the formation of the Trans-North China Orogen. 


\section{Conclusion}

The architecture of the Zanhuang Massif is three-fold. The Western Zanhuang Domain represents the eastern part of the Fuping Block whereas the Eastern Zanhuang Domain corresponds to the western margin of the Eastern Block. In between, the Central Zanhuang Domain exposes a suture zone, named the Taihangshan Suture, which represents the remnant of an oceanic basin, called the Taihang Ocean separating the Fuping Block from the Eastern Block. The structure of the Western Zanhuang Domain attests for an early $\mathrm{D}_{1}$ event that developed coevally with partial melting and anatectic plutonism. During the $\mathrm{D}_{2}$ event, rocks of the Taihang Ocean were imbricated in a stack of synmetamorphic nappes thrust toward the SE upon the Eastern Block, around $1880 \mathrm{Ma}$. The $\mathrm{D}_{3}$ and $\mathrm{D}_{4}$ events are late features, represented by east-directed folding and normal shearing, respectively. These considerations provide an additional argument for the existence of the Fuping Block that corresponds to an intervening microcontinent between the Western and Eastern Blocks. The Trans-North China Orogen formed in response to the closure of two oceanic domains at around $1880 \mathrm{Ma}$. Further works are needed to clarify the tectonic event that occurred during Archean and Early Paleoproterozoic, prior to collision.

\section{Acknowledgements}

This work was supported by grant Nos. NSFC 40472116 and NSFC 40730315 of the National Science Foundation of China. Professor Liang Zhao is greatly thanked for his comments about the geophysical data performed by his team. Comments by G.C. Zhao and an anonymous reviewer helped us to clarify some key points and improve the manuscript.

\section{References}

Black et al., 2003 L.P. Black, S.L. Kamo, C.M. Allen, J.N. Aleinikoff, D.W. Davis, R.J. Korsch and C. Foudoulis, TEMORA 1: a new zircon standard for Phanerozoic U-Pb geochronology, Chem. Geol. 200 (2003), pp. 155-170.

Black et al., 2004 L.P. Black, S.L. Kamo, C.M. Allen, D.W. Davis, J.N. Aleinikoff, J.W. Valley, R. Mundil, I.H. Campbell, R.J. Korsch, I.S. Williams and C. Foudoulis, Improved $206 \mathrm{~Pb} / 238 \mathrm{U}$ microprobe geochronology by the monitoring of a trace-element related matrix effect; SHRIMP, ID-TIMS, ELA-ICP-MS, and oxygen isotope documentation for a series of zircon standards, Chem. Geol. 205 (2004), pp. 115-140.

Cocherie et al., 1998 A. Cocherie, O. Legendre and J.J. Peucat, Geochronology of polygenetic monazites constrained by in situ electron microprobe Th-U-total lead determination: implications for lead behaviour in monazite, Geochim. Cosmochim. Acta 62 (1998), pp. 24752497.

Cocherie and Albarede, 2001 A. Cocherie and F. Albarede, An improved U-Th-Pb age calculation for electron microprobe dating of monazite, Geochim. Cosmochim. Acta $\mathbf{6 5}$ (2001), pp. 4509-4522.

Dalrymple, 1989 G.B. Dalrymple, The GLM continuous laser system for 40Ar/39Ar dating: description and performance characteristics. In: W.C. Shanks and R. Criss, Editors, New Frontiers in Stable Isotope Research USGS Bull vol. 1890 (1989), pp. 89-96.

Davis et al., 2001 G.A. Davis, Y.D. Zheng, C. Wang, B.J. Darby, C.H. Zhang and G. Gehrels, Mesozoic tectonic evolution of Yanshan fold and thrust belt with emphasis on Hebei and Liaoning Provinces, Northern China. In: M.S. Hendrix and G.A. Davis, Editors, Paleozoic and Mesozoic Tectonic Evolution of Central Asia: From Continental Assembly To 
Intracontinental Deformations vol. 194, Geological Society of American Memoir, Boulder, CO (2001), pp. 171-194.

Faure et al., 2007 M. Faure, P. Trap, W. Lin, P. Monié and O. Bruguier, The formation of the North China Craton by two Palaeoproterozoic continental collisions in Lüliang-HengshanWutaishan-Fuping massifs, Episodes 30 (2007), pp. 1-12.

Flower et al., 1998 M.F.J. Flower, K. Tamaki and N. Hoang, Mantle extrusion: a model for dispersed volcanism and DUPAL-like asthenosphere in east Asia and the western Pacific. In: M. Flower, S.L. Ching, C.H. Lo and T.Y. Lee, Editors, Mantle Dynamics and Plate Interactions in East Asia. AGU Geodynamics Series vol. 27 (1998), pp. 67-88.

Gao et al., 2002 S. Gao, R.L. Rudnick, R.W. Carlson, W.F. McDonough and Y. Liu, Re-Os evidence for replacement of ancient mantle lithosphere beneath the North China Craton, Earth Planetory Sci. Lett. 198 (2002), pp. 307-322.

Griffin et al., 1998 W.L. Griffin, Z. Andi, S.Y. O’Reilly and C.G. Ryan, Phanerozoic evolution of the lithosphere beneath the Sino-Korean craton. In: M. Flower, S.L. Ching, C.H. Lo and T.Y. Lee, Editors, Mantle Dynamics and Plate Interactions in East Asia. AGU Geodynamics Series vol. 27 (1998), pp. 107-126.

Guo et al., 2002 J.H. Guo, P.J. O'Brien and M.G. Zhai, High-pressure granulites in the Sangan area, North China Craton: metamorphic evolution, $\mathrm{P}-\mathrm{T}$ paths and geotectonic significance, J. Metamorph. Geol. 20 (2002), pp. 741-756.

Guo et al., 2005 J.H. Guo, M. Sun and M.G. Zhai, Sm-Nd and SHRIMP U-Pb zircon geochronology of high-pressure granulites in the Sanggan area, North ChinaCraton: timing of Paleoproterozoic continental collision, J. Asian Earth Sci. 24 (2005), pp. 629-642.

HBGMR, 1989 HBGMR (Henan Bureau of Geology Mineral Resources), Regional Geology of Shanxi Province, Geological Publishing House, Beijing (1989) 742 pp..

Kröner et al., 2005 A. Kröner, S.A. Wilde, J.H. Li and K.Y. Wang, Age and evolution of a late Archean to early Palaeoproterozoic upper to lower crustal section in the Wutaishan/Hengshan/ Fuping terrain of northern China, J. Asian Earth Sci. 24 (2005), pp. 577-596.

Kröner et al., 2006 A. Kröner, S.A. Wilde, G.C. Zhao, P.J. O’Brien, M. Sun, D.Y. Liu, Y.S. Wan, S.W. Liu and J.H. Guo, Zircon geochronology of mafic dykes in the Hengshan Complex of northern China: evidence for late Palaeoproterozoic rifting and subsequent highpressure event in the North China Craton, Precambrian Res. 146 (2006), pp. 45-67.

Kusky and Li, 2003 T.M. Kusky and J.H. Li, Paleoproterozoic tectonic evolution of the North China Craton, J. Asian Earth Sci. 22 (2003), pp. 23-40.

Kusky et al., 2007 T.M. Kusky, J.H. Li and M. Santosh, The Paleoproterozoic North Hebei Orogen: North China Craton's collisional suture with the Columbia Supercontinent, Gondwana Res. 12 (2007), pp. 4-28

Li and Kusky, 2007 J.H. Li and T.M. Kusky, A Late Archaean foreland fold and thrust belt in the North China Craton: Iimplications for early collisional tectonics, Gondwana Res. 12 (2007), pp. 47-66.

Lin and Wang, 2006 W. Lin and Q.C. Wang, Late Mesozoic extensional tectonics in the North China block: a crustal response to subcontinental mantle removal?, Bulletin de la Societe Geologique de France 177 (2006), pp. 287-297.

Liu et al., 2004 Y. Liu, S. Gao, H. Yuan, L. Zhou, X. Liu, X. Wang, Z. Hu and L. Wang, U$\mathrm{Pb}$ zircon ages and $\mathrm{Nd}, \mathrm{Sr}$ and $\mathrm{Pb}$ isotopes of lower crustal xenoliths from North China Craton: insights on evolution of lower continental crust, Chem. Geol. 211 (2004), pp. 87-109. Liu et al., 2006 S.W. Liu, G.C. Zhao, S.A. Wilde, G. Shu, M. Sun, Q. Li, W. Tian and J. Zhang, Th-U-Pb monazite geochronology of the Lüliang and Wutai complexes: Constraints on the tectonothermal evolution of the Trans-North China Orogen, Precambrian Res. 148 (2006), pp. 205-224. 
Ludwig, 2004 Ludwig, K.R., 2004. A geochronological toolkit for Microsoft Excel. Berkeley Geochronology Center, Special Publication, No. 4.

Ma and He, 1989 W.P. Ma and G.Q. He, Late Mesozoic magmatism in the Taihang Mountains and its tectonic implication, Geol. Rev. 29 (1) (1989), pp. 31-39.

Monié et al., 1994 P. Monié, R.L. Torres-Roldan and A. Garcia-Casco, Cooling and exhumation of the western Betic Cordilleras, ${ }^{40} \mathrm{Ar} /{ }^{40} \mathrm{Ar}$ thermochronological constraints on a collapsed terrane, Tectonophysics 238 (1994), pp. 353-379.

Monié et al., 1997 P. Monié, R. Caby and M.H. Arthaud, The neoproterozoic Brasiliano orogeny in northeast Brazil: ${ }^{40} \mathrm{Ar} /{ }^{39} \mathrm{Ar}$ and petrostructural data from Ceará, Precambrian Res. 81 (1997), pp. 241-264.

Niu et al., 1994 S.Y. Niu, C.S. Xu and L.J. Guo, The characteristics of metamorphic core complex in Taihang Mountains and its genesis, J. Hebei Col. Geol. 17 (1) (1994), pp. 43-52.

Polat et al., 2005 A. Polat, T.M. Kusky, J.H. Li, B. Fryer, R. Kerrich and K. Patrick, Geochemistry of Neoarchean (ca. 2.55-2.50 Ga) volcanic and ophiolitic rocks in the Wutaishan greenstone belt, central orogenic belt, North China Craton: implications for geodynamic setting and continental growth, Bull. Geol. Soc. Am. 117 (2005), pp. 1387-1399.

Polat et al., 2007 A. Polat, P.W.U. Appel, R. Frei, Y.M. Yuanming Pan, Y. Yıldırım Dilek, J. Ordóñez-Calderón, B. Fryer, J.A. Hollis and J.G. Raith, Field and geochemical characteristics of the Mesoarchean ( $\sim 3075 \mathrm{Ma})$ Ivisaartoq greenstone belt, southern West Greenland: Evidence for seafloor hydrothermal alteration in supra-subduction oceanic crust, Gondwana Res. 11 (2007), pp. 69-91.

Samson and Alexander, 1987 S.D. Samson and C.J.R. Alexander, New developments and applications in isotope geoscience. Calibration of the interlaboratory ${ }^{40} \mathrm{Ar} /{ }^{39} \mathrm{Ar}$ dating standard MMHb-1, Chem. Geol. (Isot Geosci. Sect) 66 (1987), pp. 27-34

Spear, 1993 F.S. Spear, Metamorphic phase equilibria and pressure-temperature-time paths, Mineralogy Society of America, Monograph, Washington, DC (1993) p. 799.

Teyssier and Whitney, 2002 C. Teyssier and D.L. Whitney, Gneiss domes and orogeny, Geology 30 (2002), pp. 1139-1142.

Trap et al., 2007 P. Trap, M. Faure, W. Lin and P. Monié, Late Palaeoproterozoic (1900$1800 \mathrm{Ma}$ ) nappe stacking and polyphase deformation in the Hengshan-Wutaishan area: implication for the understanding of the Trans-North China Belt, North China Craton, Precambrian Res. 156 (2007), pp. 85-106

Trap et al., 2008 P. Trap, M. Faure, W. Lin, P. Monié and O. Bruguier, Contrasted tectonic

styles for the Paleoproterozoic evolution of the North China Craton. Evidence for a $2.1 \mathrm{Ga}$ thermal and tectonic event in the Fuping Massif, J. Struct. Geol. 30 (2008), pp. 11091125

Trap et al., in press Trap, P., Faure, M., Lin, W., Meffre, S., in press. The Lüliang Massif: a key area for the understanding of the Palaeoproterozoic Trans-North China Belt, North China Craton. Journal of the Geological Society of London, special paper.

Wan et al., 2003 Y.S. Wan, Q. Zhang and T. Song, SHRIMP ages of detrital zircons from the Changcheng System in the Ming Tombs area, Beijing: constraints on the protolith nature and maximun deposional age of the Mesoproterozoic cover of the North China Craton, Chin. Sci. Bull. 48 (2003), pp. 2500-2506.

Wang et al., 2003 Y.J. Wang, W.M. Fan, Y. Zhang and F. Guo, Structural evolution and 40Ar/39Ar dating of the Zanhuang metamorphic domain in the North China Craton: constraints on Paleoproterozoic tectonothermal overprinting, Precambrian Res. 122 (2003), pp. 159-182.

Wang et al., 2004 Y.J. Wang, W.M. Fan and Y.H. Zhang, Geochemical, ${ }^{40} \mathrm{Ar} /{ }^{39} \mathrm{Ar}$ geochronological and $\mathrm{Sr}-\mathrm{Nd}$ isotopic constraints on the origin of Paleoproterozoic mafic 
dikes from the southern Taihang Mountains and implications for the $1800 \mathrm{Ma}$ event of the North China Craton, Precambrian Res. 135 (1-2) (2004), pp. 55-79.

Wang et al., 2006 Y.J. Wang, W.M. Fan, H.F. Zhang and T.P. Peng, Early cretaceous gabbroic rocks from the Taihang mountains: implications for a paleosubduction-related lithospheric mantle beneath the central North China Craton, Lithos 86 (2006), pp. 281-302.

Wiedenbeck et al., 1995 M. Wiedenbeck, P. Allé, F. Corfu, W.L. Griffin, M. Meier, F. Oberli, A. von Quadt, J.C. Ruddick and W. Spiegel, Three natural zircon standards for U-Th-Pb, LuHf, trace element and REE analyses, Geostandards Newslett. 19 (1995), pp. 1-23.

Wilde and Zhao, 2005 S.A. Wilde and G.C. Zhao, Archean to Paleoproterozoic evolution of the North China Craton, J. Asian Earth Sci. 24 (2005), pp. 519-522

Wilde et al., 2002 S.A. Wilde, G.C. Zhao and M. Sun, Development of the North China Craton during the Late Archaean and its final amalgamation at $1.8 \mathrm{Ga}$; some speculations on its position within a global Palaeoproterozoic Supercontinent, Gondwana Res. 5 (2002), pp. 85-94

Wu et al., 2003 F.Y. Wu, R.J. Walker, X.W. Ren, D.Y. Sun and X.H. Zhou, Osmium isotopic constraints on the age of lithospheric mantle beneath northeastern China, Chem. Geol. 196 (2003), pp. 107-129

Wu et al., 2005 F.Y. Wu, G.C. Zhao, S.A. Wilde and D.Y. Sun, Nd isotopic constraints on crustal formation in the North China Craton, J. Asian Earth Sci. 24 (2005), pp. 524-546.

$\mathrm{Xu}, 2007$ Y.G. Xu, Diachronous lithospheric thinning of the North China Craton and formation of the Daxin'anling-Taihangshan gravity lineament, Lithos 96 (2007), pp. 281298.

Zhang et al., 2007 J. Zhang, G.C. Zhao, S.Z. Li, M. Sun, S.W. Liu, S.A. Wilde, A. Kröner and C.Q. Yin, Deformation history of the Hengshan Complex: Implications for the tectonic evolution of the Trans-North China Orogen, J. Struct. Geol. 29 (2007), pp. 933-949.

Zhao et al., 1999 G.C. Zhao, P.A. Cawood and L.Z. Lu, Petrology and P-T history of the Wutai amphibolites: implications for tectonic evolution of the Wutai Complex, China Precambrian Res. 93 (1999), pp. 181-199.

Zhao et al., 2000a G.C. Zhao, P.A. Cawood, S.A. Wilde and L.Z. Lu, Metamorphism of basement rocks in the Central Zone of the North China Craton: implications for Paleoproterozoic tectonic evolution, Precambrian Res. 103 (2000), pp. 55-88.

Zhao et al., 2000b G.C. Zhao, S.A. Wilde, P.A. Cawood and L.Z. Lu, Petrology and P-T path of the Fuping mafic granulites: implications for tectonic evolution of the central zone of the North China Craton, J. Metamorphic Geol. 18 (2000), pp. 375-391

Zhao et al., 2002 G.C. Zhao, S.A. Wilde, P.A. Cawood and M. Sun, SHRIMP U-Pb zircon ages of the Fuping Complex: implications for late Archean to Paleoproterozoic accretion and assembly of the North China Craton, Am. J. Sci. 302 (2002), pp. 191-226.

Zhao et al., 2001 G.C. Zhao, S.A. Wilde, P.A. Cawood and M. Sun, Archean blocks and their boundaries in the North China Craton: lithological, geochemical, structural and P-T path constraints and tectonic evolution, Precambrian Res. 107 (2001), pp. 45-73.

Zhao et al., 1998 G.C. Zhao, S.A. Wilde, P.A. Cawood and L.Z. Lu, Thermal evolution of the Archaean basement rocks from the eastern part of the North China Craton and its bearing on tectonic setting, Int. Geol. Rev. 40 (1998), pp. 706-721.

Zhao et al., 2004 G.C. Zhao, M. Sun, S.A. Wilde and J.H. Guo, Late Archean to Palaeoproterozoic evolution of the Trans-North China Orogen: insights from synthesis of existing data from the Hengshan-Wutai-Fuping belt. In: J. Malpas, C.J.N. Fletcher, J.R. Ali and J.C. Aitchison, Editors, Aspects of the Tectonic Evolution of China, Special Publication vol. 226, Geological Society of London (2004), pp. 27-55. 
Zhao et al., 2005 G.C. Zhao, M. Sun, S.A. Wilde and S.Z. Li, Late Archean to Paleoproterozoic evolution of the North China Craton: key issues revisited, Precambrian Res. 136 (2005), pp. 177-202.

Zhao et al., 2007 G.C. Zhao, A. Kröner, S.A. Wilde, M. Sun, S.Z. Li, X.P. Li, J. Zhang, X.P. $\mathrm{Xia}$ and Y.H. He, Lithotectonic elements and geological events in the Hengshan-WutaiFuping belt: A synthesis and implications for the evolution of the Trans-North China Orogen, Geological Mag. 144 (2007), pp. 753-775.

Zheng et al., 2006 T.Y. Zheng, L. Chen, L. Zhao, W.W. Xu and R.X. Zhu, Crust-mantle structure difference across the gravity gradient zone in North China Craton: seismic image of the thinned continental crust, Phys. Earth Planetary Interiors 159 (2006), pp. 43-58.

Zheng et al., 2001 J. Zheng, S.Y. O'Reilly, W.L. Griffin, F. Lu, M. Zhang and N.J. Pearson, Relict refractory mantle beneath the eastern North China block: significance for lithosphere evolution, Lithos 57 (2001), pp. 43-66

Zheng et al., 1996 Y.Z. Zheng, Q. Zhang, Y. Wang, R. Liu, S.G. Wang, G. Zuo, S.Z. Wang, B. Lkaasuren, G. Badarch and Z. Badamgarav, Great Jurassic thrust sheets in Beishan (North Mountains)-Gobi area of China and southern Monogolia, J. Struct. Geol. 18 (1996), pp. 1111-1126. 


\section{Figures}

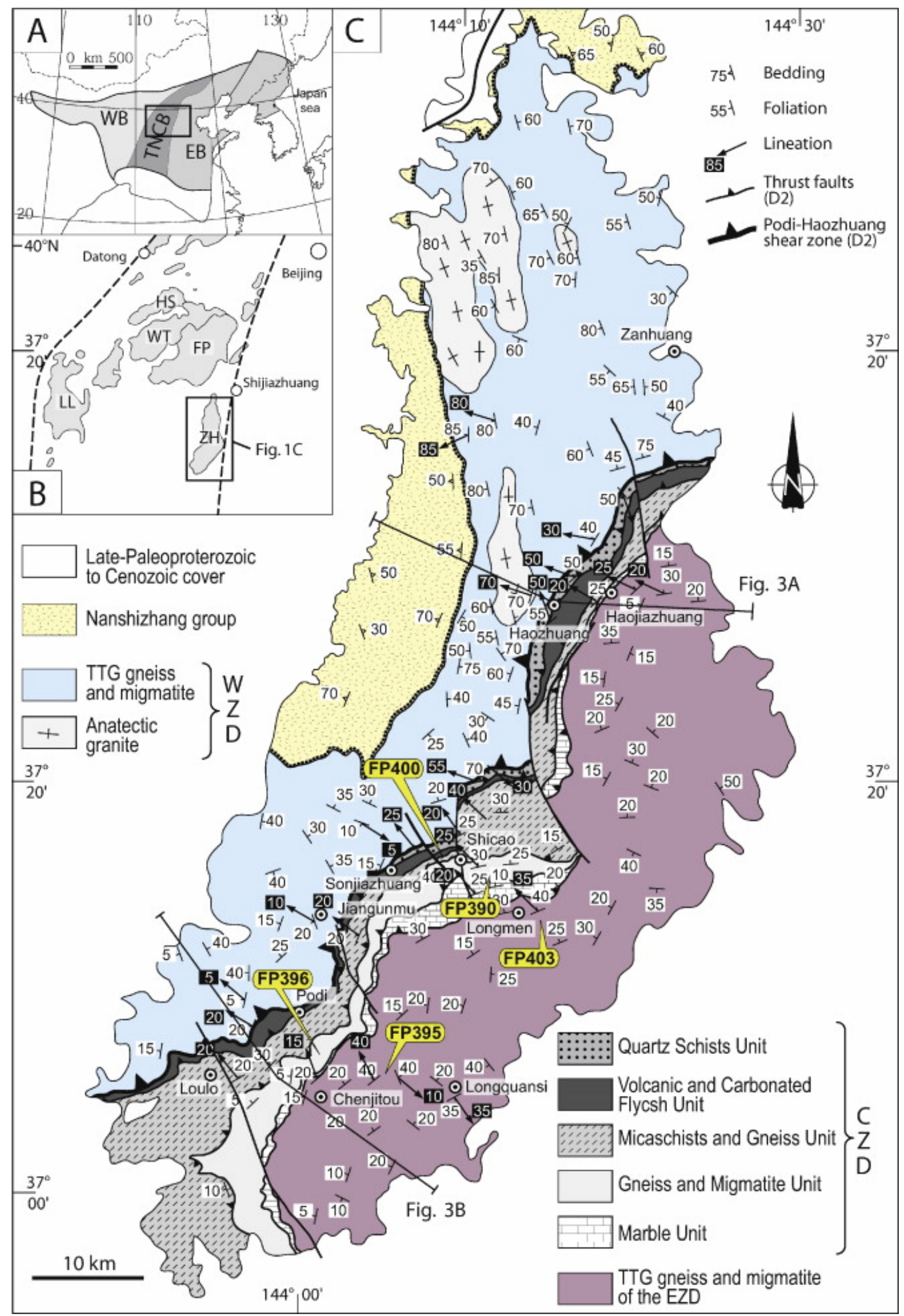

Fig. 1. (A) Simplified map of the North China Craton showing the three-fold subdivision from Zhao et al. (2001). (B) Location of the Zanhuang Massif within the Trans-North China Orogen. LL = Lüliang Massif; HS = Hengshan Massif; WT = Wutaishan Massif; FP = Fuping Massif; $\mathrm{ZH}=$ Zanhuang Massif. (C) Proposed structural map of the Zanhuang Massif, with the Western, Central and Eastern Domains described in this study. 


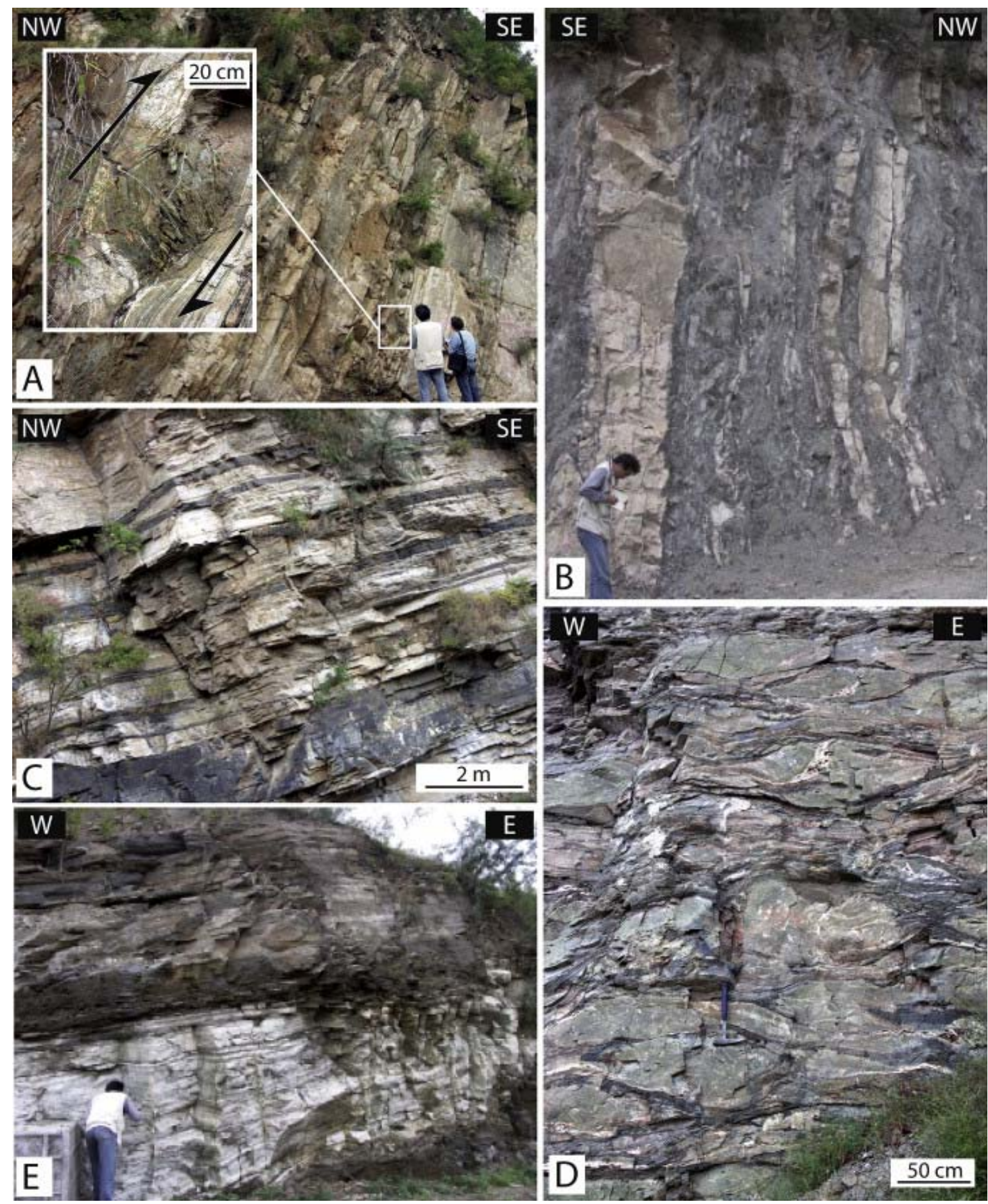

Fig. 2. Examples of lithological types within the Central Zanhuang Domain. (A) Micaceous quartzite forming decimetre-thick layers sometimes intercalated with carbonate or volcanic layers, north of Shicao. (Insert) Lense of metavolcanite showing a clear top-to-the SE kinematics $\left(\mathrm{N} 37^{\circ} 19.907^{\prime} / \mathrm{E} 114^{\circ} 11.436^{\prime}\right)$. (B) Carbonate and carbonated schist alternation, north of Shicao $\left(\mathrm{N} 37^{\circ} 19.006^{\prime} / \mathrm{E} 114^{\circ} 10.231^{\prime}\right)$. (C) Typical volcanic series made of an amphibolite and felsic gneiss layering, east of Sonjiazhuang (N37 $\left.16.633^{\prime} / \mathrm{E} 114^{\circ} 08.101^{\prime}\right)$. (D) Deformed epidosite lenses within an amphibolite matrix interpreted as a pillow basalt formation, east of Haozhuang $\left(\mathrm{N} 37^{\circ} 28.942^{\prime} / \mathrm{E} 114^{\circ} 17.520^{\prime}\right)$. (E) Fine layered coarse grained marble overlain by an amphibolite rich formation, near Longmen (N37 $\left.15.030^{\prime} / 114^{\circ} 10.768\right)$. 

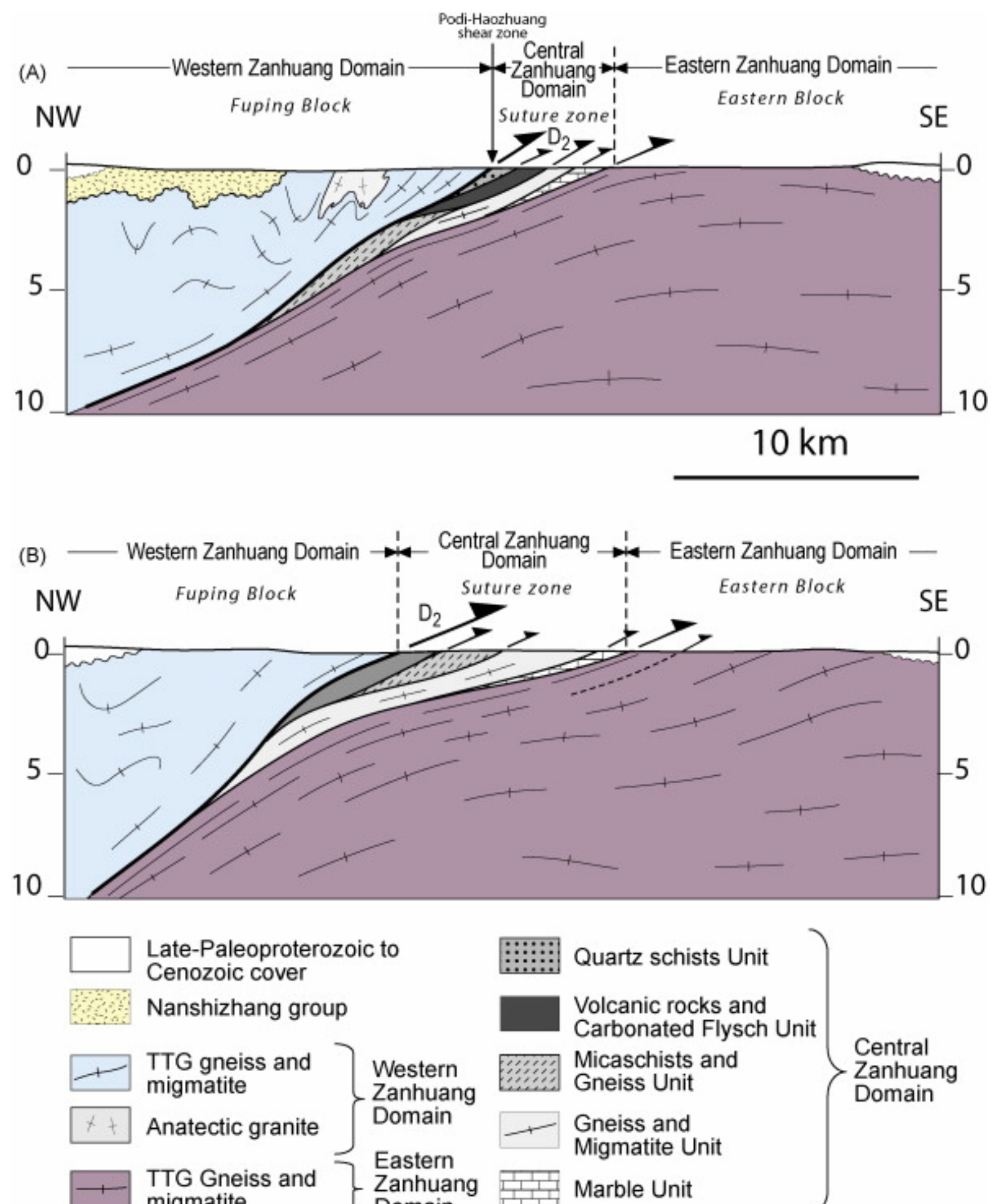

Late-Paleoproterozoic to Cenozoic cover

Nanshizhang group

TTG gneiss and migmatite

Anatectic granite

TTG Gneiss and migmatite

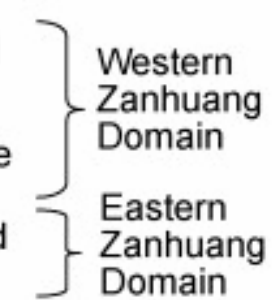

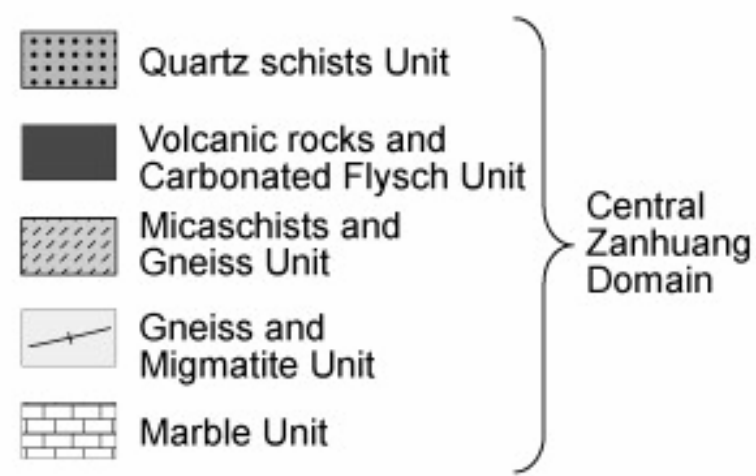

Volcanic rocks and Carbonated Flysch Unit

Micaschists and

Gneiss Unit

Zanhuang

Domain

Top-to-the East shearing (D2)

Fig. 3. Interpreted NW-SE trending crustal scale cross-sections through the Zanhuang Massif, located in Fig. 1. 

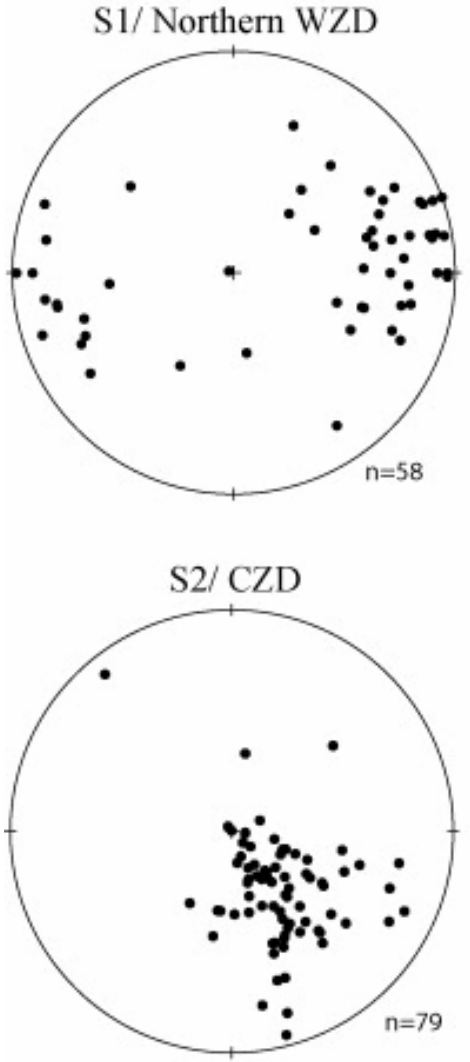

S4/ Whole massif

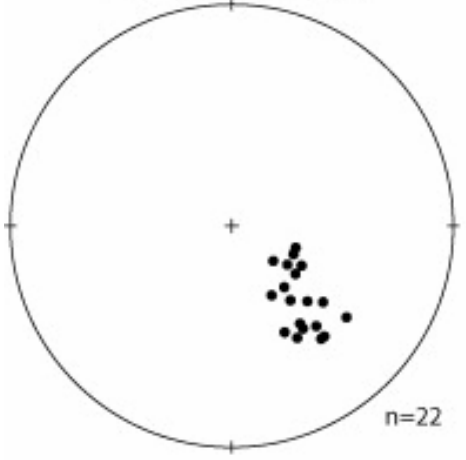

Bedding in the northern Nanshizhang Group

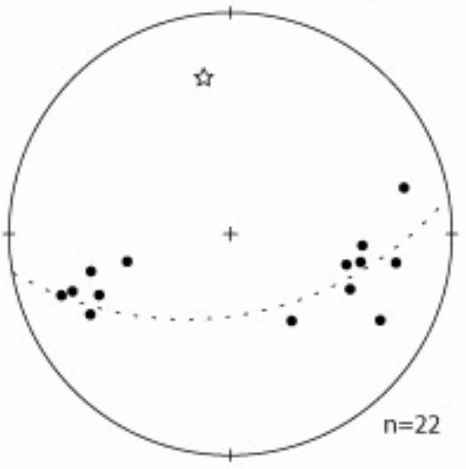

S1/ Southern WZD

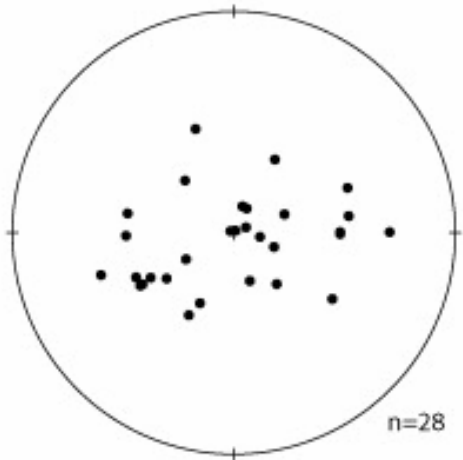

S2/ EZD

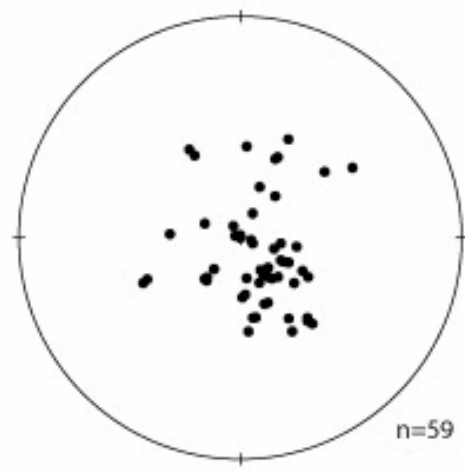

L4/ Whole massif

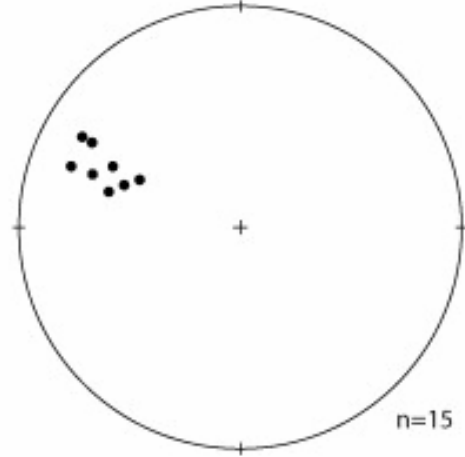

Bedding in the western Nanshizhang Group

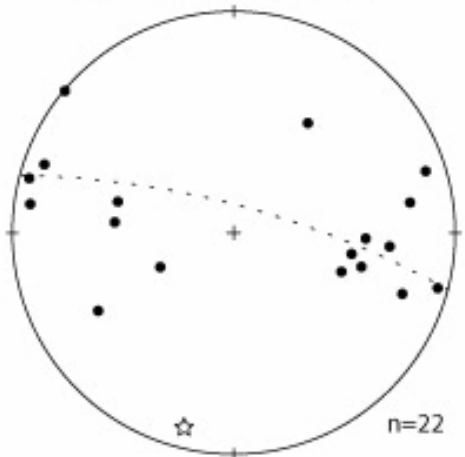

L1/ WZD

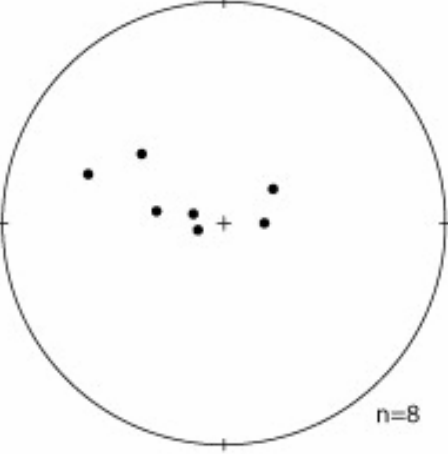

$\mathrm{L} 2$ and $\mathrm{F} 3 / \mathrm{CZD}+\mathrm{EZD}$

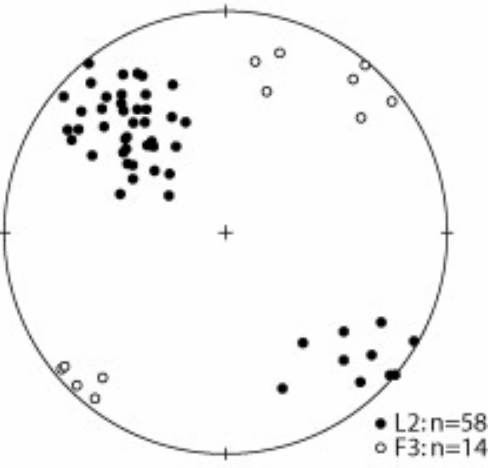

F4/ Whole massif

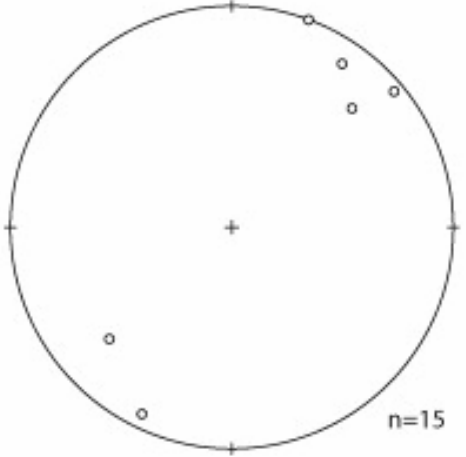

Slaty cleavage and lineation in the Nanshizhang Group

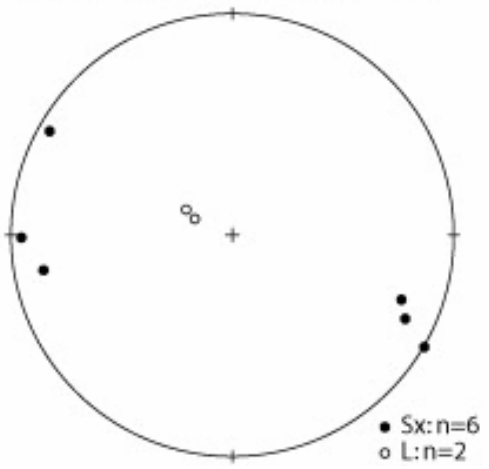

Fig. 4. Equal area, lower hemisphere Schmidt diagrams of the different structural elements recognized in the Zanhuang Massif. 

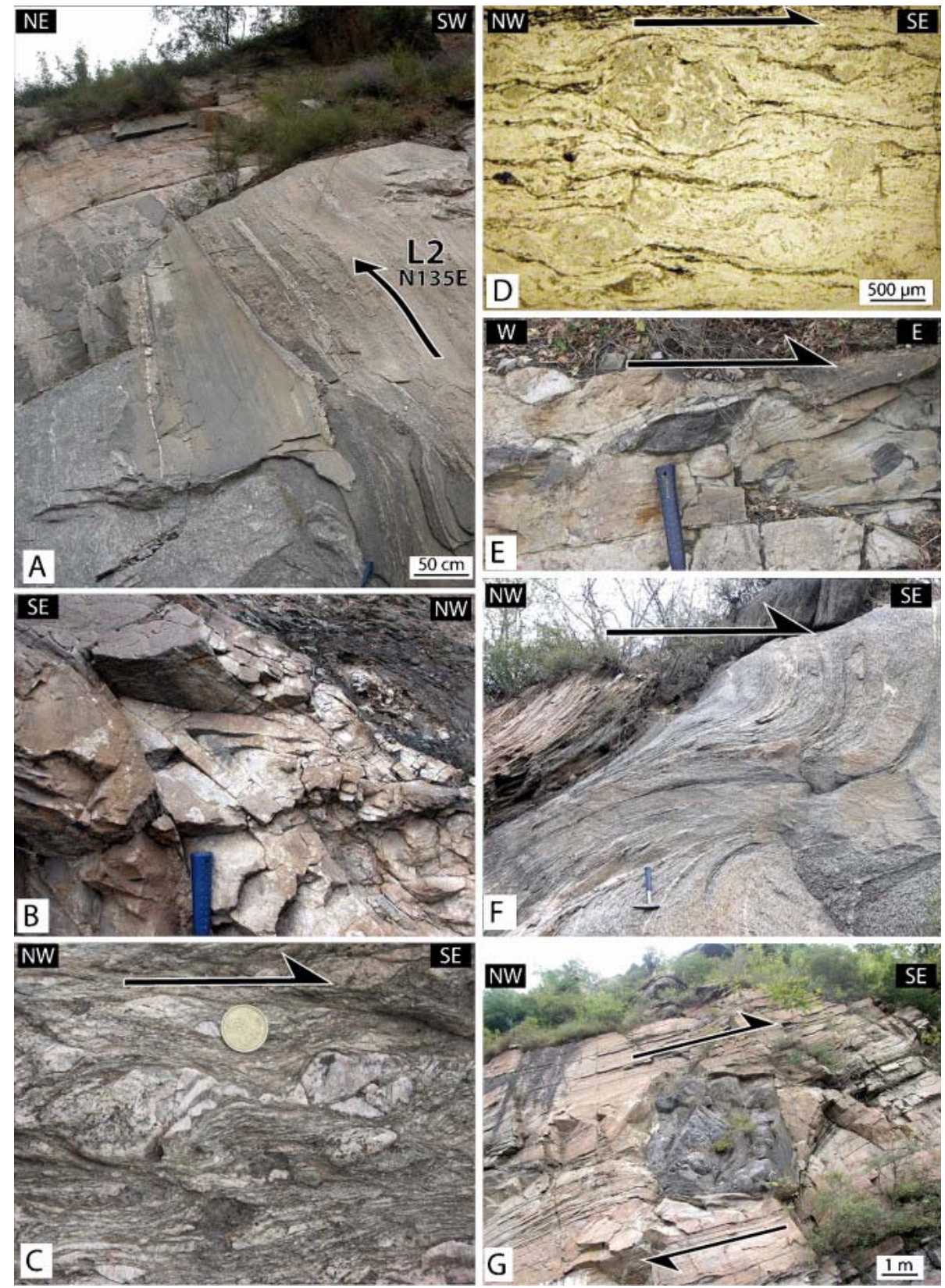

Fig. 5. Photographs of the $\mathrm{D}_{2}$ structural features. (A) $\mathrm{S}_{2}$ mylonitic surface holding a well pronounced $\mathrm{N} 135 \mathrm{E}$ trending $\mathrm{L}_{2}$ lineation along which top-to-the SE shear criteria developed, within the EZ gneiss $\left(\mathrm{N} 37^{\circ} 13.829^{\prime} / 114^{\circ} 14.765^{\prime}\right)$. (B) A-type fold within micaceous quartzite, fold axis strikes $\mathrm{N} 135 \mathrm{E}$ and plunges at $35^{\circ}$ toward the $\mathrm{NW}$ parallel to $\mathrm{L}_{2}$ $\left(\mathrm{N} 37^{\circ} 19.942^{\prime} / \mathrm{E} 114^{\circ} 11.444^{\prime}\right)$. (C) Asymmetric feldspar porphyroclast systems and associated shear zones showing a top-to-the SE shearing within an augen gneiss along the hanging wall of the Podi-Haozhuang shear zone (N37²9.181'/114 $\left.15.417^{\prime}\right)$. (D) Asymmetric top-to-the SE shear criteria within a mylonitic zone from the Gneiss and Migmatite Unit $\left(\mathrm{N} 37^{\circ} 05.926^{\prime} / \mathrm{E} 113^{\circ} 59.529^{\prime}\right)$. (E) Centimetric sigmoidal boudin of siliceous layers within marble that indicate a top-to-the SE kinematics, east of Sonjiazhuang $\left(\mathrm{N} 37^{\circ} 16.755^{\prime} / \mathrm{E} 114^{\circ} 09.220^{\prime}\right)$. (F) Flat lying ductile shear zone within a tonalitic gneiss from the EZM, shearing is top-to-the SE, east of Chenjitou (N37 $\left.05.151^{\prime} / 114^{\circ} 06.930\right)$. (G) Four metres size mafic enclave within gneissic migmatite from the Gneiss and Migmatite Unit,

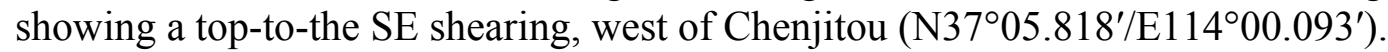



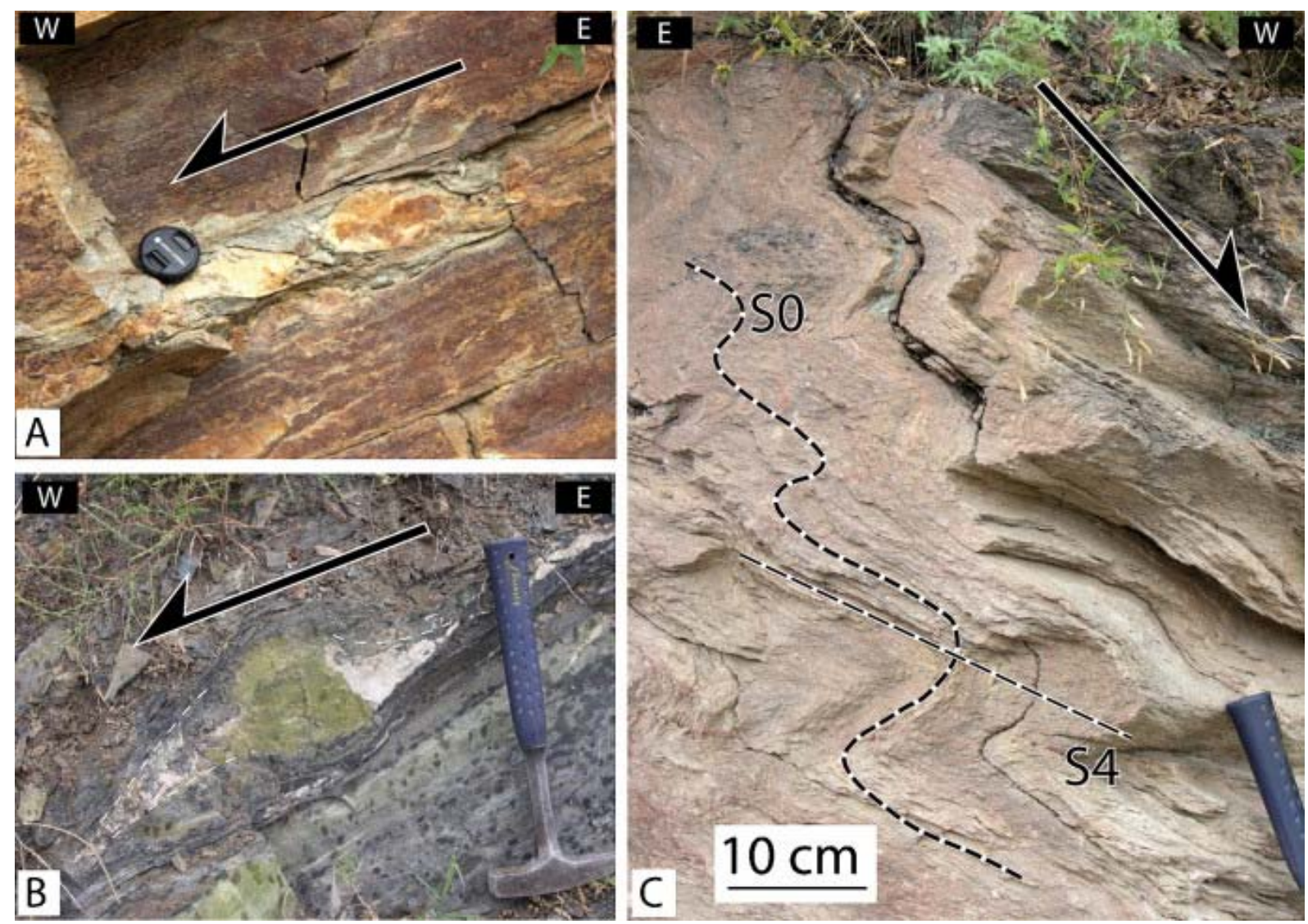

Fig. 6. Structural features of the $\mathrm{D}_{4}$ deformation. (A) Sigmoidal quartz lenses showing top-tothe NW shearing during normal $\mathrm{D}_{4}$ event, from the Micaschists and Gneiss Unit $\left(\mathrm{N} 37^{\circ} 16.726^{\prime} / \mathrm{E} 114^{\circ} 09.370^{\prime}\right)$. (B) Asymmetric quartz pressure shadows around an epidosite lense showing a top-to-the $\mathrm{W}$ shearing, along the Podi-Haozhuang shear zone $\left(\mathrm{N} 37^{\circ} 28.942^{\prime} / 114^{\circ} 17.520^{\prime}\right)$. (C) Drag folds developing within weakly metamorphosed coarse grained sandstone, western edge of southern Zanhuang Massif (N37 $\left.{ }^{\circ} 12.037^{\prime} / \mathrm{E} 113^{\circ} 54.077^{\prime}\right)$. 

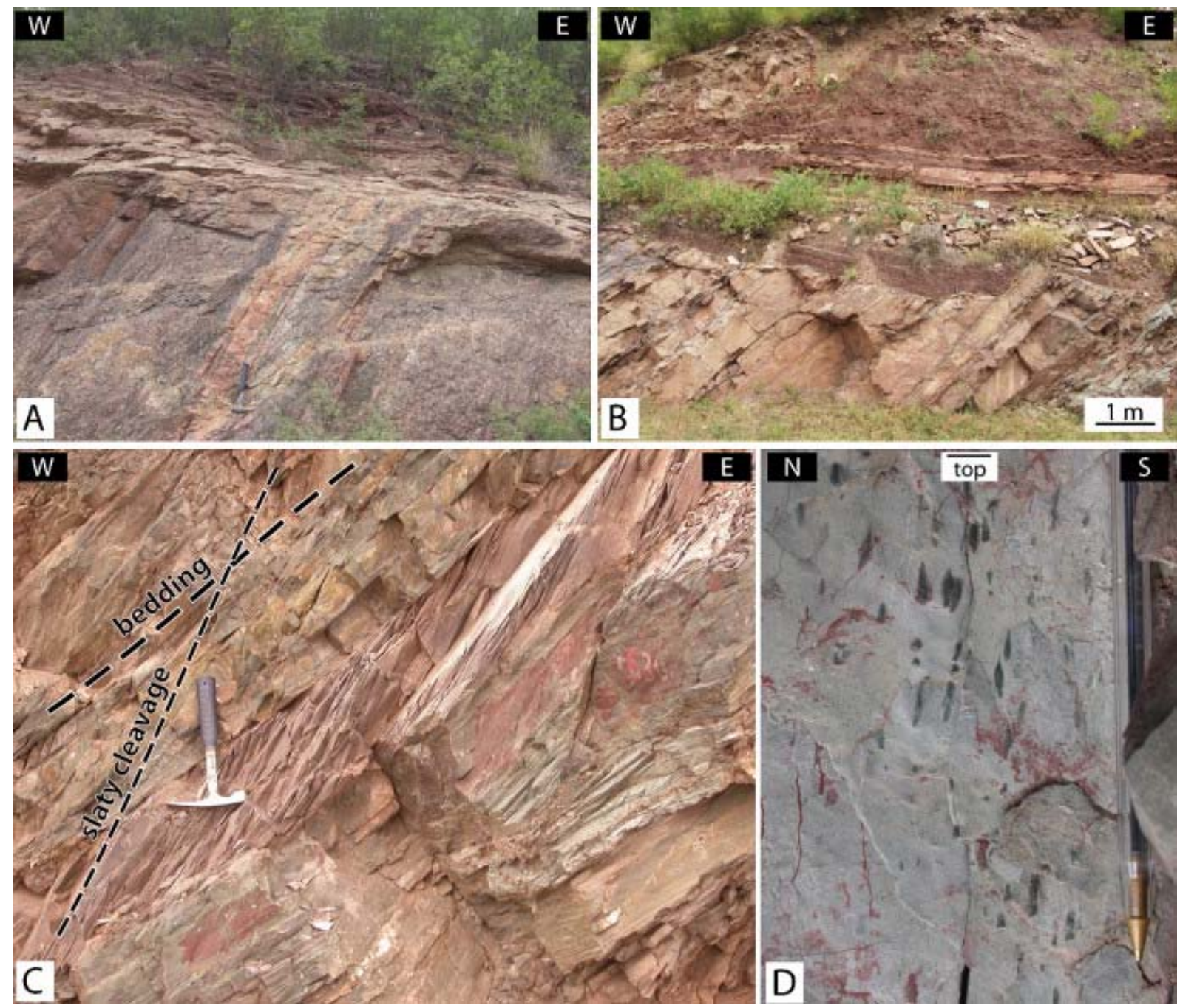

Fig. 7. A: Unconformity of the Changcheng sandstone upon EZD gneiss, eastern edge of the Zanhuang Massif (N37 $\left.37.913^{\prime} / \mathrm{E} 114^{\circ} 25.156^{\prime}\right)$. (B) Unconformity of Changcheng group upon late Paleoproterozoic Nanshizhang Group rocks $\left(\mathrm{N} 37^{\circ} 48.953 / \mathrm{E}^{\circ} 114^{\circ} 05.012^{\prime}\right)$. (C) Highly dipping slaty cleavage that mainly develops within the mudstone layers and cut across the bedding of the Nanshizhang rocks $\left(\mathrm{N} 37^{\circ} 49.617^{\prime} / \mathrm{E} 114^{\circ} 04.585^{\prime}\right)$. (D) Stretching lineation marked by elongated black-greenish mudstone aggregates that plunges at high angle toward the WNW, within the Nanshizhang rocks $\left(\mathrm{N} 37^{\circ} 48.953 / \mathrm{E}^{\circ} 114^{\circ} 05.012^{\prime}\right)$. 

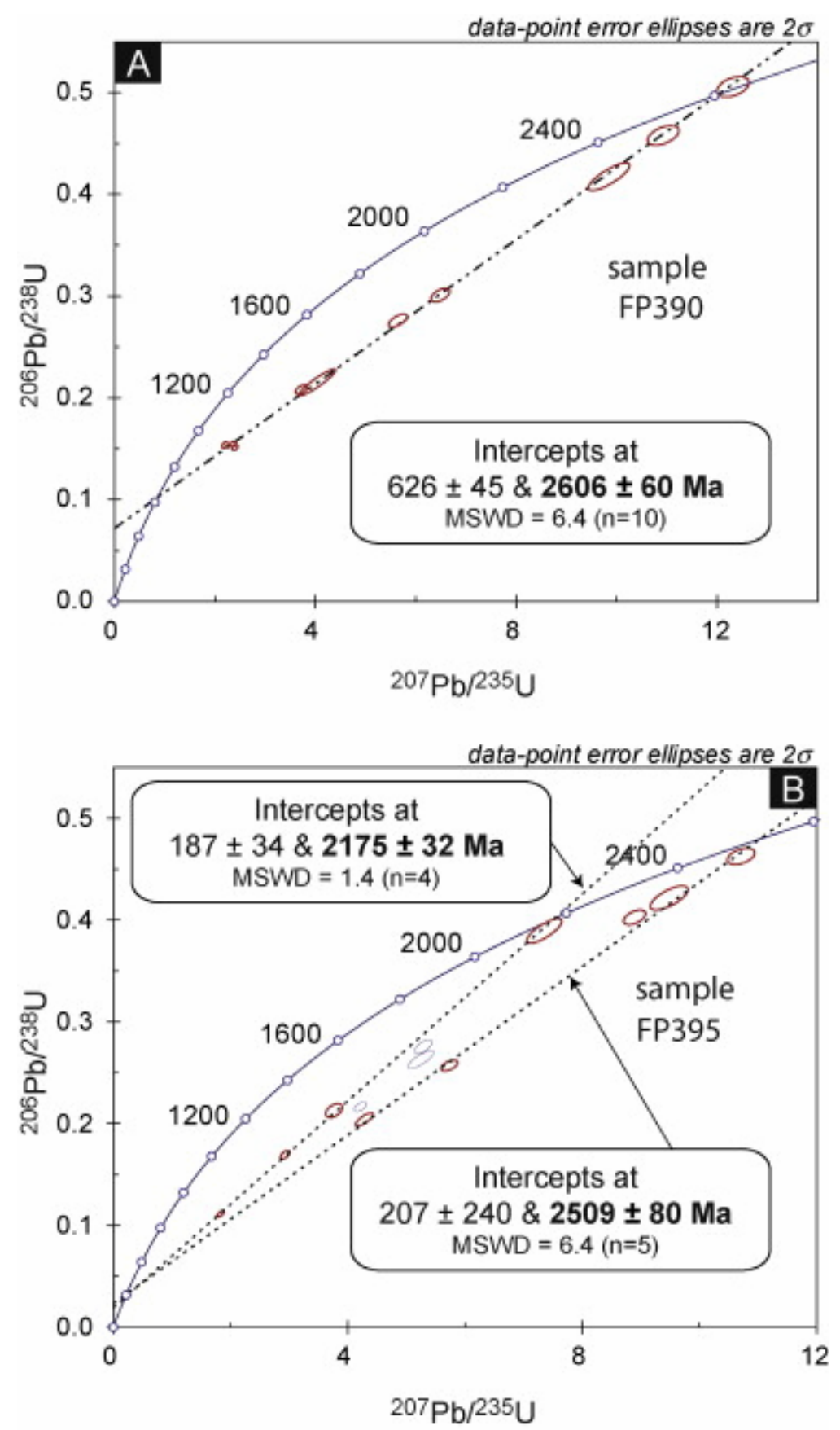

Fig. 8. Concordia diagrams of LA-ICP-MS U-Pb zircon analytical results for samples FP390 (A) and FP395 (B). 

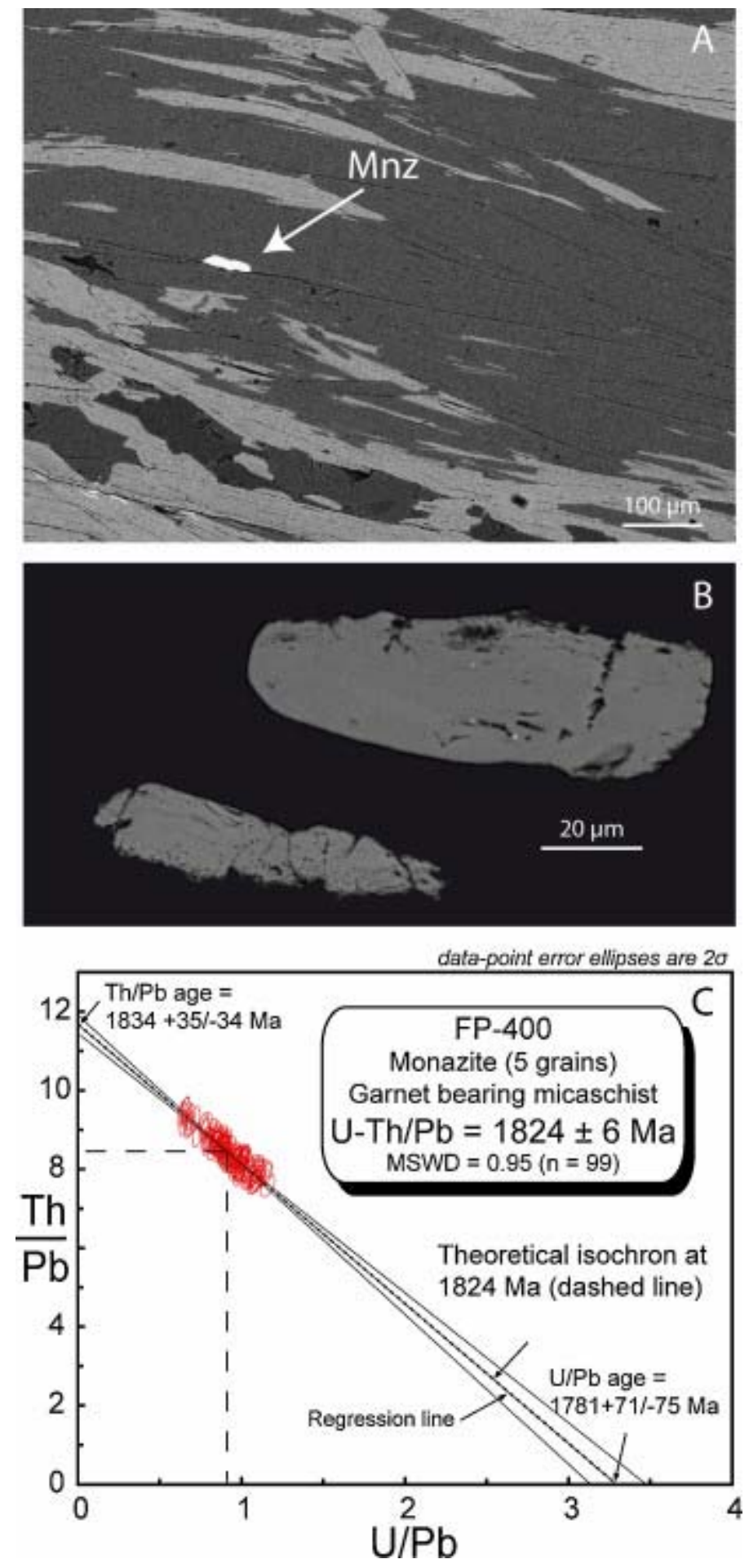

Fig. 9. (A) Back-scattered electron (BSE) image showing the textural relationship between monazite and the $\mathrm{S}_{4}$ foliation. (B) Detail BSE image of monazite grain without zonation. (C) Isochron diagram (according to Cocherie and Albarede, 2001) for monazites from the sample FP400. The mean age is calculated at the population centroid (dashed and dotted lines) where the error is the smallest. 

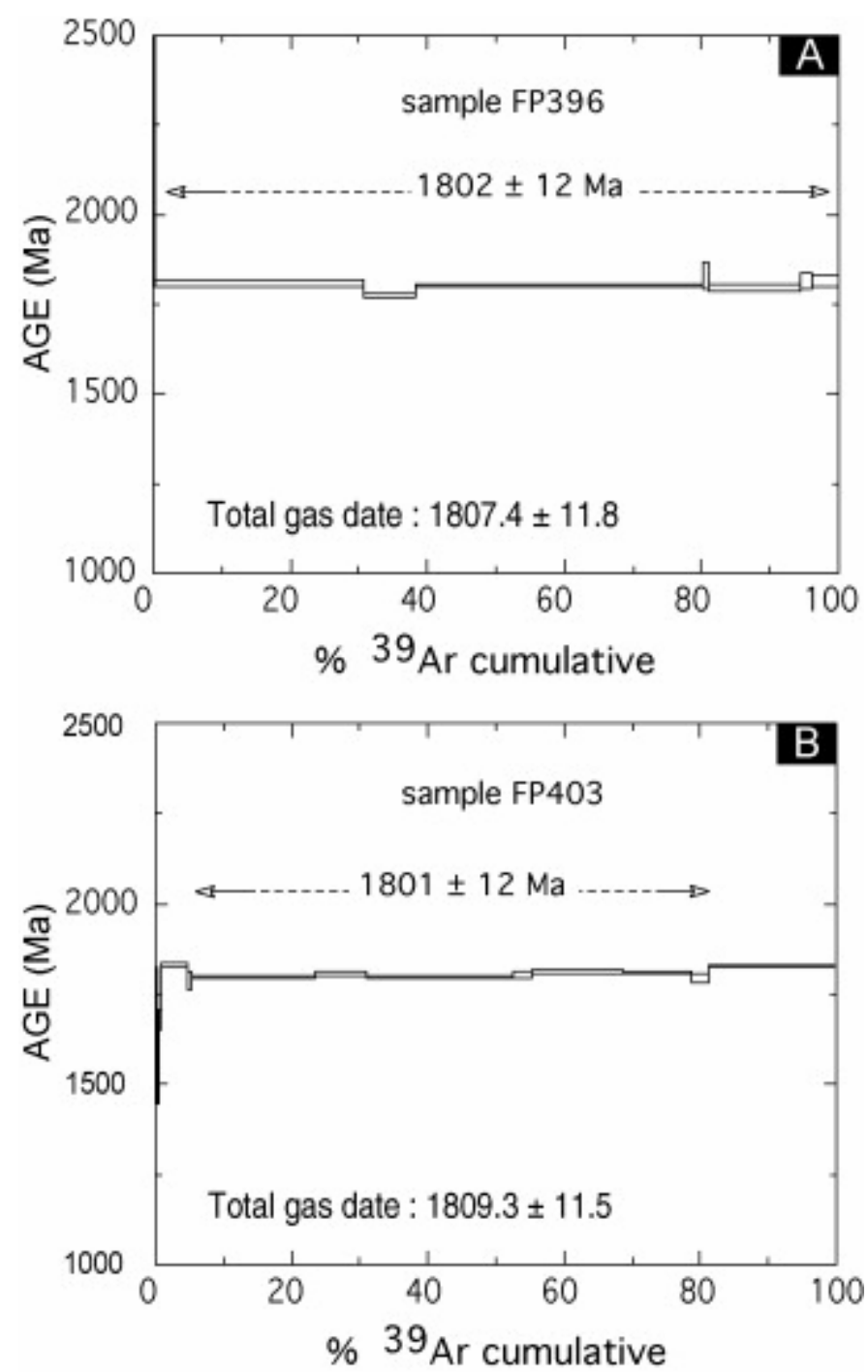

Fig. 10. ${ }^{40} \mathrm{Ar}-{ }^{39} \mathrm{Ar}$ amphibole age spectra for sample FP396 (A) and FP403 (B). 


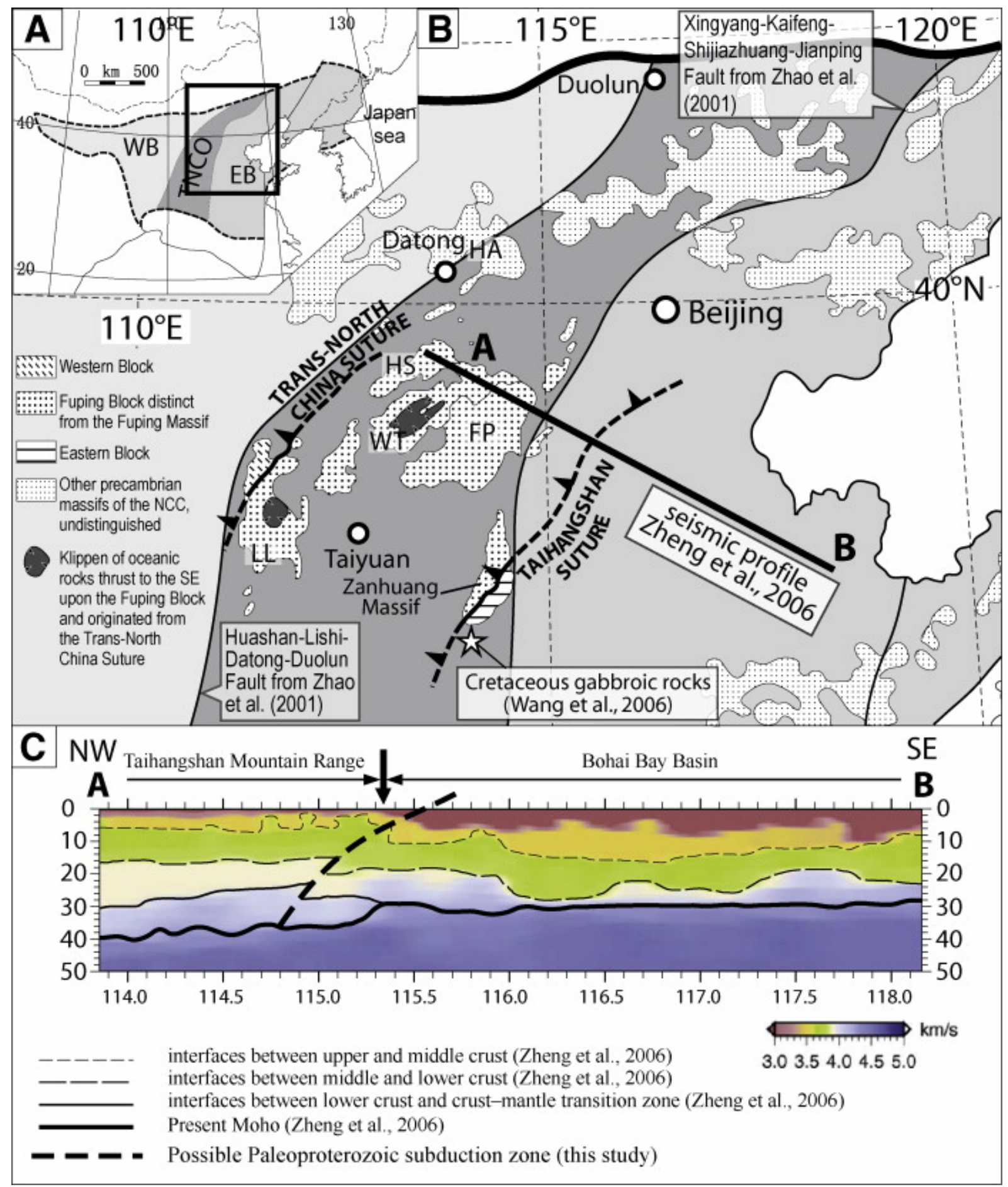

Fig. 11. (A) The three-fold subdivision of the North China Craton of Zhao et al. (2001). (B) Focus on the Trans-North China Orogen with the locations of: (i) the Huashan-Lishi-DatongDuolun and Xingyang-Kaifeng-Shijiazhuang-Jianping Faults from Zhao et al. (2001), (ii) the two established suture zones ([Faure et al., 2007] and [Trap et al., in press], this study), (iii) the crustal scale seismic profile from Zheng et al. (2006), and (iv) the Cretaceous gabbroic rocks studied by Wang et al. (2006). 


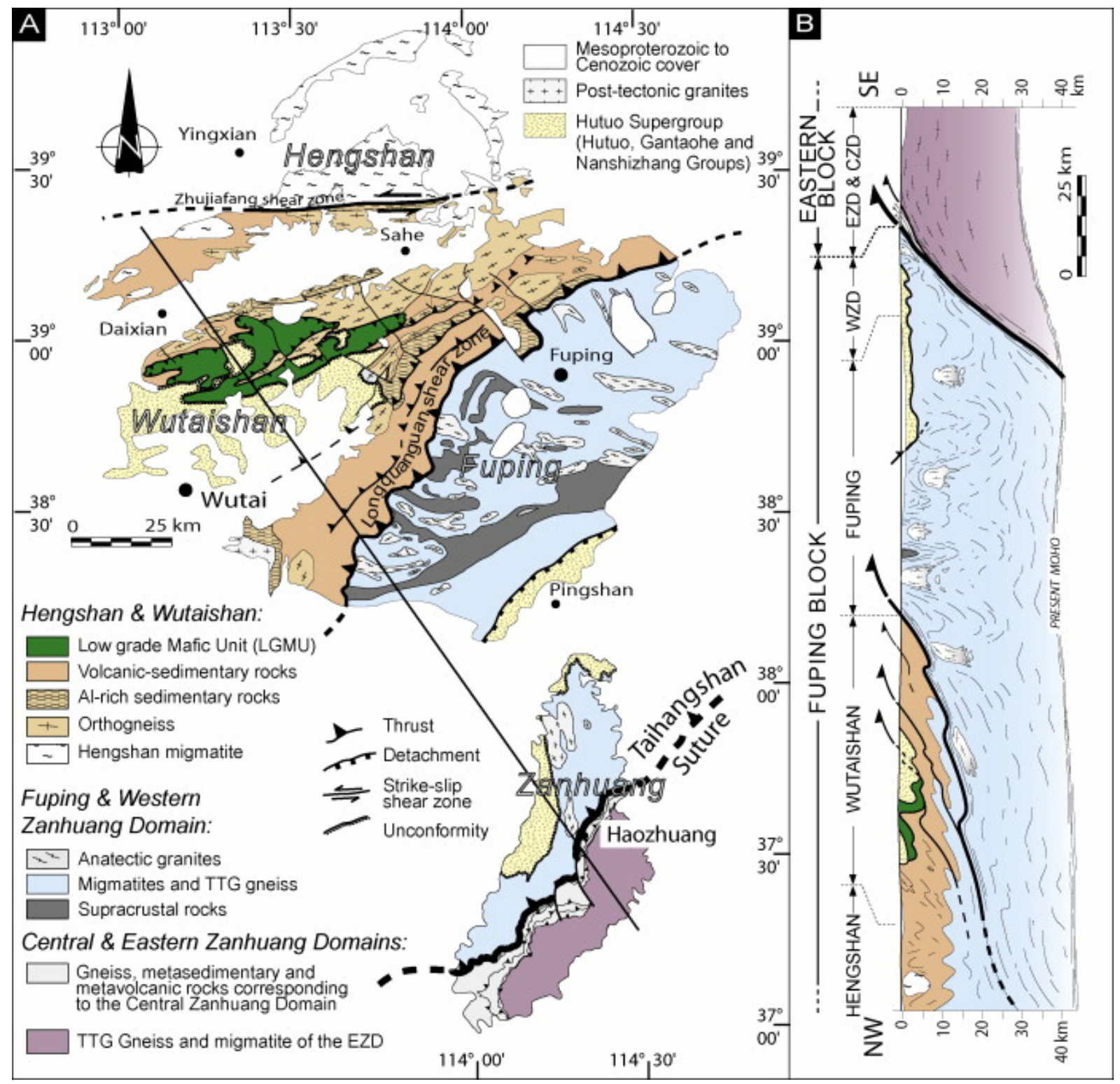

Fig. 12. Geological map (A) and cross-section (B) showing the tectonic units and their structural relationships recognized in the Hengshan-Wutaishan-Fuping-Zanhuang Massifs ([Trap et al., 2007] and [Trap et al., 2008], this study). 
Tables 
Table 1. Deformation events recognized in the Zanhuang Massif and related structural features, metamorphic conditions and ages.

\begin{tabular}{|c|c|c|c|c|c|c|}
\hline Event & Location & $\begin{array}{l}\text { Structural features } \\
\text { Foliation }\end{array}$ & Lineation & Folds & $\begin{array}{l}\text { Metamorphic } \\
\text { conditions }\end{array}$ & Age (Ma) \\
\hline D1 & $\begin{array}{l}\text { Dominant in the WZD. } \\
\text { Some remnants within } \\
\text { migmatite of the EZD and } \\
\text { within the Gneiss and } \\
\text { Migmatite Unit of the CZD. }\end{array}$ & $\begin{array}{l}\text { S1 foliation striking } \\
\text { N170E, dipping toward } \\
\text { the W and the E, defining } \\
\text { km-scale antiforms and } \\
\text { synforms. }\end{array}$ & $\begin{array}{ll}\text { L1 lineation, } & \text { steeply } \\
\text { plunging with } & \text { E- and } \\
\text { W-directed } & \text { normal } \\
\text { shearing. } & \end{array}$ & & $\begin{array}{lr}\text { During } & \text { partial } \\
\text { melting } & \text { and } \\
\text { anatectic } & \\
\text { plutonism. } & \end{array}$ & ca. 2100 \\
\hline D3 & $\begin{array}{l}\text { Dominant in the Central } \\
\text { Zanhuang Domain. }\end{array}$ & & & $\begin{array}{l}\text { N50E metre to } \\
\text { hundreds of metres } \\
\text { scale F3 folds, } \\
\text { overturned toward } \\
\text { the SE }\end{array}$ & & $\begin{array}{l}\text { Between } \\
1880 \text { and } \\
1824 \mathrm{Ma}\end{array}$ \\
\hline D4 & $\begin{array}{l}\text { Dominant in the CZD, some } \\
\text { evidence within the EZD } \\
\text { and WZD. }\end{array}$ & $\begin{array}{l}\text { Localized normal shear } \\
\text { zones. S4 strikes N40- } \\
60 \mathrm{E} \text { and dips toward the } \\
\text { NW. }\end{array}$ & $\begin{array}{l}\text { L4 strikes N110-120E } \\
\text { and plunges } 20-50^{\circ} \\
\text { toward WNW. }\end{array}$ & $\begin{array}{l}\mathrm{cm} \text { - to dm-scale drag } \\
\text { folds overturned to } \\
\text { the W. }\end{array}$ & $\begin{array}{l}\text { Greenschist facies } \\
\text { conditions. }\end{array}$ & 1824 \\
\hline \multicolumn{2}{|c|}{$\begin{array}{l}\text { Deformation within the Nanshizhang } \\
\text { Group }\end{array}$} & $\begin{array}{l}\text { N90E-N120E highly } \\
\text { deeping slaty cleavage. }\end{array}$ & $\begin{array}{l}\text { Stretching lineation } \\
\text { plunging highly } \\
\text { toward the WNW. }\end{array}$ & $\begin{array}{lr}\text { East } & \text { verging } \mathrm{km}- \\
\text { scale } & \text { recumbent } \\
\text { folds. } & \end{array}$ & $\begin{array}{l}\text { Sub-greenschist } \\
\text { facies conditions. }\end{array}$ & $\begin{array}{l}\text { Between } \\
1880 \text { and } \\
1824 \mathrm{Ma}\end{array}$ \\
\hline
\end{tabular}


Table 2. : U-Pb LA-ICP-MS analyses for zircons from samples FP390 and FP395.

\begin{tabular}{|c|c|c|c|c|c|c|c|c|c|c|c|c|c|c|c|c|c|}
\hline & Pb & $\underline{\text { Th }}$ & $\underline{\mathbf{U}}$ & $\begin{array}{l}\mathbf{T} \\
\mathbf{h} \\
\mathbf{U} \\
\end{array}$ & $\begin{array}{l}207 \\
\mathbf{P b} \\
235 \\
\mathrm{U} \\
\end{array}$ & $1 \sigma$ & $\begin{array}{l}207 \\
\mathbf{P b} \\
206 \\
\mathrm{U} \\
\end{array}$ & $1 \sigma$ & $\begin{array}{l}206 \\
\mathbf{P b} \\
238 \\
\mathrm{U} \\
\end{array}$ & $1 \sigma$ & $\begin{array}{l}206 \\
\mathbf{P b} \\
238 \\
\mathbf{U} \\
\text { age } \\
\text { (M } \\
\text { a) } \\
\end{array}$ & $\begin{array}{l}1 \\
\boldsymbol{\sigma} \\
-\end{array}$ & $\begin{array}{l}207 \\
\mathbf{P b} \\
235 \\
\mathbf{U} \\
\text { age } \\
\text { (M } \\
\text { a) } \\
\end{array}$ & $\begin{array}{l}1 \\
\boldsymbol{\sigma} \\
-\end{array}$ & $\begin{array}{l}207 \\
\mathbf{P b} \\
206 \\
\mathbf{U} \\
\text { age } \\
\text { (M } \\
\text { a) } \\
\end{array}$ & $\begin{array}{l}1 \\
\boldsymbol{\sigma} \\
-\end{array}$ & $\begin{array}{l}\% \\
\text { Con } \\
\text { c. } \\
\end{array}$ \\
\hline \multicolumn{18}{|c|}{ TTG gneiss (FP390), Western Zanhuang Domain (N37º15.558'/E114º10.093') } \\
\hline $\mathrm{j} 104 \mathrm{k} 1$ & $\begin{array}{l}15 \\
5\end{array}$ & $\begin{array}{l}11 \\
7\end{array}$ & $\begin{array}{l}61 \\
0\end{array}$ & $\begin{array}{l}0 . \\
76\end{array}$ & $\begin{array}{l}5.5 \\
1\end{array}$ & $\begin{array}{l}0 . \\
20\end{array}$ & $\begin{array}{l}0.1 \\
44\end{array}$ & $\begin{array}{l}0.0 \\
02\end{array}$ & $\begin{array}{l}0.2 \\
85\end{array}$ & $\begin{array}{l}0.0 \\
08\end{array}$ & $\begin{array}{l}16 \\
15\end{array}$ & $\begin{array}{l}3 \\
8\end{array}$ & $\begin{array}{l}19 \\
03\end{array}$ & $\begin{array}{l}3 \\
2\end{array}$ & $\begin{array}{l}22 \\
74\end{array}$ & $\begin{array}{l}2 \\
6\end{array}$ & $\begin{array}{l}29.5 \\
8\end{array}$ \\
\hline $\mathrm{j} 104 \mathrm{k} 2$ & $\begin{array}{l}2 \\
3\end{array}$ & $\begin{array}{l}27 \\
6\end{array}$ & $\begin{array}{l}16 \\
45\end{array}$ & $\begin{array}{l}1 . \\
09\end{array}$ & $\begin{array}{l}2.4 \\
0\end{array}$ & $\begin{array}{l}0 . \\
02\end{array}$ & $\begin{array}{l}0.1 \\
21\end{array}$ & $\begin{array}{l}0.0 \\
01\end{array}$ & $\begin{array}{l}0.1 \\
51\end{array}$ & $\begin{array}{l}0.0 \\
01\end{array}$ & $\begin{array}{l}90 \\
9\end{array}$ & 6 & $\begin{array}{l}12 \\
43\end{array}$ & 6 & $\begin{array}{l}19 \\
67\end{array}$ & $\begin{array}{l}1 \\
7\end{array}$ & $\begin{array}{l}158 . \\
72\end{array}$ \\
\hline $\mathrm{j} 104 \mathrm{k} 3$ & $\begin{array}{l}31 \\
6\end{array}$ & $\begin{array}{l}40 \\
9\end{array}$ & $\begin{array}{l}19 \\
97\end{array}$ & $\begin{array}{l}1 . \\
30\end{array}$ & $\begin{array}{l}2.3 \\
6\end{array}$ & $\begin{array}{l}0 . \\
02\end{array}$ & $\begin{array}{l}0.1 \\
16\end{array}$ & $\begin{array}{l}0.0 \\
01\end{array}$ & $\begin{array}{l}0.1 \\
55\end{array}$ & $\begin{array}{l}0.0 \\
01\end{array}$ & $\begin{array}{l}92 \\
8\end{array}$ & 6 & $\begin{array}{l}12 \\
31\end{array}$ & 7 & $\begin{array}{l}19 \\
00\end{array}$ & $\begin{array}{l}1 \\
7\end{array}$ & $\begin{array}{l}151 . \\
55\end{array}$ \\
\hline $\mathrm{j} 104 \mathrm{k} 4$ & $\begin{array}{l}31 \\
2\end{array}$ & $\begin{array}{l}45 \\
4\end{array}$ & $\begin{array}{l}19 \\
97\end{array}$ & $\begin{array}{l}1 . \\
46\end{array}$ & $\begin{array}{l}2.2 \\
0\end{array}$ & $\begin{array}{l}0 . \\
02\end{array}$ & $\begin{array}{l}0.1 \\
08\end{array}$ & $\begin{array}{l}0.0 \\
01\end{array}$ & $\begin{array}{l}0.1 \\
54\end{array}$ & $\begin{array}{l}0.0 \\
01\end{array}$ & $\begin{array}{l}92 \\
3\end{array}$ & 7 & $\begin{array}{l}11 \\
81\end{array}$ & 7 & $\begin{array}{l}17 \\
69\end{array}$ & $\begin{array}{l}1 \\
8\end{array}$ & $\begin{array}{l}129 . \\
87\end{array}$ \\
\hline $\mathrm{j} 104 \mathrm{k} 5$ & $\begin{array}{l}19 \\
5\end{array}$ & $\begin{array}{l}26 \\
2\end{array}$ & $\begin{array}{l}91 \\
3\end{array}$ & $\begin{array}{l}1 . \\
34\end{array}$ & $\begin{array}{l}3.7 \\
2\end{array}$ & $\begin{array}{l}0 . \\
05\end{array}$ & $\begin{array}{l}0.1 \\
36\end{array}$ & $\begin{array}{l}0.0 \\
02\end{array}$ & $\begin{array}{l}0.2 \\
08\end{array}$ & $\begin{array}{l}0.0 \\
02\end{array}$ & $\begin{array}{l}12 \\
20\end{array}$ & $\begin{array}{l}1 \\
0\end{array}$ & $\begin{array}{l}15 \\
76\end{array}$ & $\begin{array}{l}1 \\
0\end{array}$ & $\begin{array}{l}21 \\
80\end{array}$ & $\begin{array}{l}2 \\
0\end{array}$ & $\begin{array}{l}112 . \\
50\end{array}$ \\
\hline j104k6 & $\begin{array}{l}22 \\
6\end{array}$ & $\begin{array}{l}14 \\
4\end{array}$ & $\begin{array}{l}11 \\
01\end{array}$ & $\begin{array}{l}0 . \\
64\end{array}$ & $\begin{array}{l}4.0 \\
4\end{array}$ & $\begin{array}{l}0 . \\
15\end{array}$ & & $\begin{array}{l}0.0 \\
02\end{array}$ & $\begin{array}{l}0.2 \\
15\end{array}$ & $\begin{array}{l}0.0 \\
05\end{array}$ & $\begin{array}{l}12 \\
58\end{array}$ & $\begin{array}{l}2 \\
8\end{array}$ & $\begin{array}{l}16 \\
43\end{array}$ & $\begin{array}{l}3 \\
0\end{array}$ & $\begin{array}{l}22 \\
11\end{array}$ & $\begin{array}{l}2 \\
9\end{array}$ & $\begin{array}{l}39.3 \\
5\end{array}$ \\
\hline $\mathrm{j} 104 \mathrm{k} 7$ & $\begin{array}{l}22 \\
2\end{array}$ & $\begin{array}{l}13 \\
5\end{array}$ & $\begin{array}{l}91 \\
4\end{array}$ & $\begin{array}{l}0 . \\
61\end{array}$ & $\begin{array}{l}4.3 \\
9\end{array}$ & $\begin{array}{l}0 . \\
05\end{array}$ & $\begin{array}{l}0.1 \\
41\end{array}$ & $\begin{array}{l}0.0 \\
01\end{array}$ & $\begin{array}{l}0.2 \\
37\end{array}$ & $\begin{array}{l}0.0 \\
02\end{array}$ & $\begin{array}{l}13 \\
73\end{array}$ & $\begin{array}{l}1 \\
1\end{array}$ & $\begin{array}{l}17 \\
10\end{array}$ & $\begin{array}{l}1 \\
0\end{array}$ & $\begin{array}{l}22 \\
38\end{array}$ & $\begin{array}{l}1 \\
7\end{array}$ & $\begin{array}{l}97.4 \\
6\end{array}$ \\
\hline $\mathrm{j} 104 \mathrm{k} 8$ & $\begin{array}{l}17 \\
9\end{array}$ & 90 & $\begin{array}{l}63 \\
2\end{array}$ & $\begin{array}{l}0 . \\
50\end{array}$ & $\begin{array}{l}5.6 \\
4\end{array}$ & $\begin{array}{l}0 . \\
08\end{array}$ & $\begin{array}{l}0.1 \\
55\end{array}$ & $\begin{array}{l}0.0 \\
02\end{array}$ & $\begin{array}{l}0.2 \\
76\end{array}$ & $\begin{array}{l}0.0 \\
03\end{array}$ & $\begin{array}{l}15 \\
72\end{array}$ & $\begin{array}{l}1 \\
3\end{array}$ & $\begin{array}{l}19 \\
23\end{array}$ & $\begin{array}{l}1 \\
2\end{array}$ & $\begin{array}{l}24 \\
04\end{array}$ & $\begin{array}{l}1 \\
8\end{array}$ & $\begin{array}{l}91.9 \\
9\end{array}$ \\
\hline j104k9 & $\begin{array}{l}21 \\
5\end{array}$ & $\begin{array}{l}13 \\
6\end{array}$ & $\begin{array}{l}67 \\
5\end{array}$ & $\begin{array}{l}0 . \\
63\end{array}$ & $\begin{array}{l}6.4 \\
9\end{array}$ & $\begin{array}{l}0 . \\
08\end{array}$ & $\begin{array}{l}0.1 \\
64\end{array}$ & $\begin{array}{l}0.0 \\
02\end{array}$ & $\begin{array}{l}0.3 \\
01\end{array}$ & $\begin{array}{l}0.0 \\
03\end{array}$ & $\begin{array}{l}16 \\
96\end{array}$ & $\begin{array}{l}1 \\
3\end{array}$ & $\begin{array}{l}20 \\
44\end{array}$ & $\begin{array}{l}1 \\
0\end{array}$ & $\begin{array}{l}24 \\
96\end{array}$ & $\begin{array}{l}1 \\
7\end{array}$ & $\begin{array}{l}92.8 \\
2\end{array}$ \\
\hline $\mathrm{j} 104 \mathrm{k} 10$ & $\begin{array}{l}15 \\
7\end{array}$ & $\begin{array}{l}14 \\
0\end{array}$ & $\begin{array}{l}35 \\
0\end{array}$ & $\begin{array}{l}0 . \\
89\end{array}$ & $\begin{array}{l}9.8 \\
4\end{array}$ & $\begin{array}{l}0 . \\
17\end{array}$ & $\begin{array}{l}0.1 \\
80\end{array}$ & $\begin{array}{l}0.0 \\
02\end{array}$ & $\begin{array}{l}0.4 \\
17\end{array}$ & $\begin{array}{l}0.0 \\
05\end{array}$ & $\begin{array}{l}22 \\
48\end{array}$ & $\begin{array}{l}2 \\
5\end{array}$ & $\begin{array}{l}24 \\
20\end{array}$ & $\begin{array}{l}1 \\
6\end{array}$ & $\begin{array}{l}26 \\
51\end{array}$ & $\begin{array}{l}1 \\
7\end{array}$ & $\begin{array}{l}53.0 \\
3\end{array}$ \\
\hline j104k11 & $\begin{array}{l}10 \\
7\end{array}$ & 79 & $\begin{array}{l}21 \\
9\end{array}$ & $\begin{array}{l}0 . \\
74\end{array}$ & $\begin{array}{l}10 . \\
92\end{array}$ & $\begin{array}{l}0 . \\
13\end{array}$ & $\begin{array}{l}0.1 \\
83\end{array}$ & $\begin{array}{l}0.0 \\
02\end{array}$ & $\begin{array}{l}0.4 \\
58\end{array}$ & $\begin{array}{l}0.0 \\
04\end{array}$ & $\begin{array}{l}24 \\
31\end{array}$ & $\begin{array}{l}1 \\
7\end{array}$ & $\begin{array}{l}25 \\
17\end{array}$ & $\begin{array}{l}1 \\
1\end{array}$ & $\begin{array}{l}26 \\
78\end{array}$ & $\begin{array}{l}1 \\
7\end{array}$ & $\begin{array}{l}76.9 \\
2\end{array}$ \\
\hline $\mathrm{j} 104 \mathrm{k} 12$ & $\begin{array}{l}12 \\
3\end{array}$ & 59 & $\begin{array}{l}22 \\
6\end{array}$ & $\begin{array}{l}0 . \\
48\end{array}$ & $\begin{array}{l}12 . \\
31\end{array}$ & $\begin{array}{l}0 . \\
13\end{array}$ & $\begin{array}{l}0.1 \\
86\end{array}$ & $\begin{array}{l}0.0 \\
02\end{array}$ & $\begin{array}{l}0.5 \\
06\end{array}$ & $\begin{array}{l}0.0 \\
04\end{array}$ & $\begin{array}{l}26 \\
38\end{array}$ & $\begin{array}{l}1 \\
7\end{array}$ & $\begin{array}{l}26 \\
29\end{array}$ & $\begin{array}{l}1 \\
0\end{array}$ & $\begin{array}{l}27 \\
08\end{array}$ & $\begin{array}{l}1 \\
7\end{array}$ & $\begin{array}{l}77.9 \\
2\end{array}$ \\
\hline \multicolumn{18}{|c|}{ Migmatite leucosonme (FP395), Western Zanhuang Domain $\left(N 37^{\circ} 05.264^{\prime} / E 114^{\circ} 04.822^{\prime}\right)$} \\
\hline j104L1 & $\begin{array}{l}32 \\
3\end{array}$ & $\begin{array}{l}26 \\
72\end{array}$ & $\begin{array}{l}25 \\
32\end{array}$ & $\begin{array}{l}8 . \\
28\end{array}$ & $\begin{array}{l}1.8 \\
3\end{array}$ & $\begin{array}{l}0 . \\
03\end{array}$ & $\begin{array}{l}0.1 \\
27\end{array}$ & $\begin{array}{l}0.0 \\
01\end{array}$ & $\begin{array}{l}0.1 \\
11\end{array}$ & $\begin{array}{l}0.0 \\
01\end{array}$ & $\begin{array}{l}68 \\
1\end{array}$ & 7 & $\begin{array}{l}10 \\
55\end{array}$ & 9 & $\begin{array}{l}20 \\
62\end{array}$ & $\begin{array}{l}1 \\
8\end{array}$ & $\begin{array}{l}141 . \\
90\end{array}$ \\
\hline j104L2 & $\begin{array}{l}39 \\
0\end{array}$ & $\begin{array}{l}50 \\
4\end{array}$ & $\begin{array}{l}22 \\
75\end{array}$ & $\begin{array}{l}1 . \\
29\end{array}$ & $\begin{array}{l}2.9 \\
3\end{array}$ & $\begin{array}{l}0 . \\
03\end{array}$ & $\begin{array}{l}0.1 \\
33\end{array}$ & $\begin{array}{l}0.0 \\
01\end{array}$ & $\begin{array}{l}0.1 \\
69\end{array}$ & $\begin{array}{l}0.0 \\
02\end{array}$ & $\begin{array}{l}10 \\
09\end{array}$ & 9 & $\begin{array}{l}13 \\
89\end{array}$ & 8 & $\begin{array}{l}21 \\
37\end{array}$ & $\begin{array}{l}1 \\
6\end{array}$ & $\begin{array}{l}115 . \\
67\end{array}$ \\
\hline j104L3 & $\begin{array}{l}88 \\
7\end{array}$ & $\begin{array}{l}16 \\
92\end{array}$ & $\begin{array}{l}38 \\
75\end{array}$ & $\begin{array}{l}1 . \\
91\end{array}$ & $\begin{array}{l}4.2 \\
8\end{array}$ & $\begin{array}{l}0 . \\
06\end{array}$ & $\begin{array}{l}0.1 \\
61\end{array}$ & $\begin{array}{l}0.0 \\
01\end{array}$ & $\begin{array}{l}0.2 \\
04\end{array}$ & $\begin{array}{l}0.0 \\
03\end{array}$ & $\begin{array}{l}11 \\
98\end{array}$ & $\begin{array}{l}1 \\
4\end{array}$ & $\begin{array}{l}16 \\
90\end{array}$ & $\begin{array}{l}1 \\
2\end{array}$ & $\begin{array}{l}24 \\
71\end{array}$ & $\begin{array}{l}1 \\
6\end{array}$ & $\begin{array}{l}89.1 \\
7\end{array}$ \\
\hline
\end{tabular}




\begin{tabular}{|c|c|c|c|c|c|c|c|c|c|c|c|c|c|c|c|c|c|}
\hline & Pb & $\begin{array}{c}\text { Th } \\
\end{array}$ & $\underline{\mathbf{U}}$ & $\begin{array}{l}\mathbf{T} \\
\mathbf{h} \\
\mathbf{U} \\
\end{array}$ & $\begin{array}{l}207 \\
\mathbf{P b} \\
235 \\
\mathbf{U} \\
\end{array}$ & $1 \sigma$ & $\begin{array}{l}207 \\
\mathbf{P b} \\
\mathbf{2 0 6} \\
\mathrm{U} \\
\end{array}$ & $1 \sigma$ & $\begin{array}{l}206 \\
\mathbf{P b} \\
238 \\
\mathbf{U} \\
\end{array}$ & $1 \sigma$ & $\begin{array}{l}206 \\
\text { Pb } \\
238 \\
\text { U } \\
\text { age } \\
\text { (M } \\
\text { a) } \\
\end{array}$ & $\begin{array}{l}1 \\
\boldsymbol{\sigma} \\
-\end{array}$ & $\begin{array}{l}207 \\
\mathbf{P b} \\
235 \\
\mathbf{U} \\
\text { age } \\
\text { (M } \\
\text { a) } \\
\end{array}$ & $\begin{array}{l}\mathbf{1} \\
\boldsymbol{\sigma} \\
-\end{array}$ & $\begin{array}{l}207 \\
\text { Pb } \\
206 \\
\text { U } \\
\text { age } \\
\text { (M } \\
\text { a) } \\
\end{array}$ & $\begin{array}{l}\mathbf{1} \\
\boldsymbol{\sigma} \\
-\end{array}$ & $\begin{array}{l}\% \\
\text { Con } \\
\text { c. } \\
\end{array}$ \\
\hline j104L4 & $\begin{array}{l}78 \\
0\end{array}$ & $\begin{array}{l}14 \\
79\end{array}$ & $\begin{array}{l}33 \\
44\end{array}$ & $\begin{array}{l}1 . \\
90\end{array}$ & $\begin{array}{l}4.2 \\
1\end{array}$ & $\begin{array}{l}0 . \\
04\end{array}$ & $\begin{array}{l}0.1 \\
45\end{array}$ & $\begin{array}{l}0.0 \\
01\end{array}$ & $\begin{array}{l}0.2 \\
17\end{array}$ & $\begin{array}{l}0.0 \\
02\end{array}$ & $\begin{array}{l}12 \\
64\end{array}$ & $\begin{array}{l}1 \\
0\end{array}$ & $\begin{array}{l}13 \\
76\end{array}$ & 8 & $\begin{array}{l}23 \\
43\end{array}$ & $\begin{array}{l}1 \\
5\end{array}$ & $\begin{array}{l}117 . \\
92\end{array}$ \\
\hline j104L5 & $\begin{array}{l}11 \\
28\end{array}$ & $\begin{array}{l}88 \\
02\end{array}$ & $\begin{array}{l}36 \\
67\end{array}$ & $\begin{array}{l}7 . \\
80\end{array}$ & $\begin{array}{l}5.7 \\
3\end{array}$ & $\begin{array}{l}0 . \\
06\end{array}$ & $\begin{array}{l}0.1 \\
71\end{array}$ & $\begin{array}{l}0.0 \\
02\end{array}$ & $\begin{array}{l}0.2 \\
57\end{array}$ & $\begin{array}{l}0.0 \\
02\end{array}$ & $\begin{array}{l}14 \\
75\end{array}$ & $\begin{array}{l}1 \\
1\end{array}$ & $\begin{array}{l}19 \\
36\end{array}$ & 9 & $\begin{array}{l}25 \\
69\end{array}$ & $\begin{array}{l}1 \\
5\end{array}$ & $\begin{array}{l}115 . \\
54\end{array}$ \\
\hline j104L6 & $\begin{array}{l}99 \\
3\end{array}$ & $\begin{array}{l}96 \\
4\end{array}$ & $\begin{array}{l}34 \\
45\end{array}$ & $\begin{array}{l}0 . \\
97\end{array}$ & $\begin{array}{l}5.2 \\
9\end{array}$ & $\begin{array}{l}0 . \\
06\end{array}$ & $\begin{array}{l}0.1 \\
48\end{array}$ & $\begin{array}{l}0.0 \\
01\end{array}$ & $\begin{array}{l}0.2 \\
76\end{array}$ & $\begin{array}{l}0.0 \\
03\end{array}$ & $\begin{array}{l}15 \\
70\end{array}$ & $\begin{array}{l}1 \\
4\end{array}$ & $\begin{array}{l}18 \\
67\end{array}$ & $\begin{array}{l}1 \\
0\end{array}$ & $\begin{array}{l}23 \\
22\end{array}$ & $\begin{array}{l}1 \\
6\end{array}$ & $\begin{array}{l}83.8 \\
4\end{array}$ \\
\hline j104L7 & $\begin{array}{l}22 \\
82\end{array}$ & $\begin{array}{l}15 \\
28\end{array}$ & $\begin{array}{l}57 \\
20\end{array}$ & $\begin{array}{l}0 . \\
67\end{array}$ & $\begin{array}{l}7.3 \\
5\end{array}$ & $\begin{array}{l}0 . \\
12\end{array}$ & $\begin{array}{l}0.1 \\
45\end{array}$ & $\begin{array}{l}0.0 \\
01\end{array}$ & $\begin{array}{l}0.3 \\
89\end{array}$ & $\begin{array}{l}0.0 \\
05\end{array}$ & $\begin{array}{l}21 \\
20\end{array}$ & $\begin{array}{l}2 \\
3\end{array}$ & $\begin{array}{l}21 \\
55\end{array}$ & $\begin{array}{l}1 \\
5\end{array}$ & $\begin{array}{l}22 \\
87\end{array}$ & $\begin{array}{l}1 \\
8\end{array}$ & $\begin{array}{l}50.0 \\
8\end{array}$ \\
\hline j104L8 & $\begin{array}{l}92 \\
1\end{array}$ & $\begin{array}{l}36 \\
2\end{array}$ & $\begin{array}{l}22 \\
18\end{array}$ & $\begin{array}{l}0 . \\
39\end{array}$ & $\begin{array}{l}8.8 \\
9\end{array}$ & $\begin{array}{l}0 . \\
08\end{array}$ & $\begin{array}{l}0.1 \\
69\end{array}$ & $\begin{array}{l}0.0 \\
01\end{array}$ & $\begin{array}{l}0.4 \\
03\end{array}$ & $\begin{array}{l}0.0 \\
03\end{array}$ & $\begin{array}{l}21 \\
82\end{array}$ & $\begin{array}{l}1 \\
3\end{array}$ & $\begin{array}{l}23 \\
27\end{array}$ & 8 & $\begin{array}{l}25 \\
52\end{array}$ & $\begin{array}{l}1 \\
3\end{array}$ & $\begin{array}{l}95.6 \\
7\end{array}$ \\
\hline j104L9 & $\begin{array}{l}58 \\
3\end{array}$ & $\begin{array}{l}40 \\
3\end{array}$ & $\begin{array}{l}26 \\
78\end{array}$ & $\begin{array}{l}0 . \\
69\end{array}$ & $\begin{array}{l}3.7 \\
7\end{array}$ & $\begin{array}{l}0 . \\
06\end{array}$ & $\begin{array}{l}0.1 \\
36\end{array}$ & $\begin{array}{l}0.0 \\
02\end{array}$ & $\begin{array}{l}0.2 \\
13\end{array}$ & $\begin{array}{l}0.0 \\
03\end{array}$ & $\begin{array}{l}12 \\
44\end{array}$ & $\begin{array}{l}1 \\
5\end{array}$ & $\begin{array}{l}15 \\
85\end{array}$ & $\begin{array}{l}1 \\
3\end{array}$ & $\begin{array}{l}21 \\
77\end{array}$ & $\begin{array}{l}2 \\
6\end{array}$ & $\begin{array}{l}74.2 \\
6\end{array}$ \\
\hline j104L10 & $\begin{array}{l}26 \\
0\end{array}$ & $\begin{array}{l}13 \\
7\end{array}$ & $\begin{array}{l}93 \\
9\end{array}$ & $\begin{array}{l}0 . \\
53\end{array}$ & $\begin{array}{l}5.2 \\
5\end{array}$ & $\begin{array}{l}0 . \\
09\end{array}$ & $\begin{array}{l}0.1 \\
53\end{array}$ & $\begin{array}{l}0.0 \\
02\end{array}$ & $\begin{array}{l}0.2 \\
63\end{array}$ & $\begin{array}{l}0.0 \\
04\end{array}$ & $\begin{array}{l}15 \\
06\end{array}$ & $\begin{array}{l}1 \\
9\end{array}$ & $\begin{array}{l}18 \\
60\end{array}$ & $\begin{array}{l}1 \\
5\end{array}$ & $\begin{array}{l}23 \\
82\end{array}$ & $\begin{array}{l}1 \\
7\end{array}$ & $\begin{array}{l}63.8 \\
6\end{array}$ \\
\hline j104L11 & $\begin{array}{l}21 \\
5\end{array}$ & $\begin{array}{l}29 \\
3\end{array}$ & $\begin{array}{l}43 \\
4\end{array}$ & $\begin{array}{l}1 . \\
36\end{array}$ & $\begin{array}{l}9.4 \\
8\end{array}$ & $\begin{array}{l}0 . \\
13\end{array}$ & $\begin{array}{l}0.1 \\
73\end{array}$ & $\begin{array}{l}0.0 \\
02\end{array}$ & $\begin{array}{l}0.4 \\
22\end{array}$ & $\begin{array}{l}0.0 \\
05\end{array}$ & $\begin{array}{l}22 \\
68\end{array}$ & $\begin{array}{l}2 \\
2\end{array}$ & $\begin{array}{l}23 \\
86\end{array}$ & $\begin{array}{l}1 \\
3\end{array}$ & $\begin{array}{l}25 \\
89\end{array}$ & $\begin{array}{l}1 \\
7\end{array}$ & $\begin{array}{l}59.3 \\
0\end{array}$ \\
\hline j104L12 & $\begin{array}{l}40 \\
7\end{array}$ & $\begin{array}{l}28 \\
1\end{array}$ & $\begin{array}{l}79 \\
9\end{array}$ & $\begin{array}{l}0 . \\
69\end{array}$ & $\begin{array}{l}10 . \\
71\end{array}$ & $\begin{array}{l}0 . \\
10\end{array}$ & $\begin{array}{l}0.1 \\
78\end{array}$ & $\begin{array}{l}0.0 \\
02\end{array}$ & $\begin{array}{l}0.4 \\
63\end{array}$ & $\begin{array}{l}0.0 \\
03\end{array}$ & $\begin{array}{l}24 \\
51\end{array}$ & $\begin{array}{l}1 \\
4\end{array}$ & $\begin{array}{l}24 \\
98\end{array}$ & 8 & $\begin{array}{l}26 \\
36\end{array}$ & $\begin{array}{l}1 \\
4\end{array}$ & $\begin{array}{l}91.3 \\
7\end{array}$ \\
\hline
\end{tabular}

Table 3. : Summary of $\mathrm{U}-\mathrm{Th} / \mathrm{Pb}$ EPMA for monazites from sample FP400.

\begin{tabular}{|l|l|l|}
\hline $\mathrm{U}(\mathrm{ppm}) \pm \sigma$ std.dev. & Th $(\mathrm{ppm}) \pm \sigma$ std. dev. & $\mathrm{Pb}(\mathrm{ppm}) \pm \sigma$ std. dev. \\
\hline $5114 \pm 108$ & $47,880 \pm 958$ & $5650 \pm 117$ \\
\hline $\mathrm{Th} / \mathrm{U} \pm \sigma$ std. dev. & Isochron age $\pm 2 \sigma \mathrm{Ma}$ & No. of data \\
\hline $9.4 \pm 8.8$ & $1,824 \pm 6$ & 99 \\
\hline
\end{tabular}


Table 4. ${ }^{40} \mathrm{Ar} /{ }^{39} \mathrm{Ar}$ isotopic analytical data for incremental heating experiments on amphibole grains from samples FP396 and FP403.

\begin{tabular}{|c|c|c|c|c|c|c|c|c|c|}
\hline Step & $40 / 39$ & $38 / 39$ & $37 / 39$ & $\begin{array}{l}36 / 39 \\
(E-3)\end{array}$ & $\begin{array}{l}\text { F39Ar } \\
\text { released }\end{array}$ & $\% 40 *$ & $40 * / 39 \mathrm{~K}$ & $\begin{array}{l}\text { Age } \\
\text { (Ma) }\end{array}$ & $\begin{array}{l} \pm 1 \text { sd } \\
\text { (Ma) }\end{array}$ \\
\hline $\begin{array}{l}\text { FP396 } \\
\text { amphibole }\end{array}$ & \multicolumn{9}{|c|}{$J=0.008921$} \\
\hline 1 & 546.621 & 0.499 & 24.49482 & 240.462 & 0.15 & 87.33 & 485.12 & 3018.1 & 107.6 \\
\hline 2 & 379.821 & 0.218 & 7.55569 & 56.302 & 0.28 & 95.76 & 365.53 & 2615.0 & 115.0 \\
\hline 3 & 192.533 & 0.020 & 6.41969 & 0.597 & 30.85 & 99.99 & 193.63 & 1810.1 & 7.4 \\
\hline 4 & 186.865 & 0.018 & 5.41723 & 0.000 & 38.33 & 99.99 & 187.92 & 1776.1 & 6.7 \\
\hline 5 & 192.101 & 0.019 & 5.27189 & 2.970 & 80.16 & 99.74 & 192.26 & 1802.0 & 3.6 \\
\hline 6 & 206.592 & 0.033 & 4.11186 & 33.801 & 81.01 & 95.31 & 197.43 & 1832.4 & 37.6 \\
\hline 7 & 190.858 & 0.017 & 5.99741 & 3.491 & 94.51 & 99.69 & 191.01 & 1794.6 & 9.0 \\
\hline 8 & 198.102 & 0.018 & 5.21152 & 16.253 & 96.00 & 97.77 & 194.33 & 1814.2 & 20.6 \\
\hline 9 & 195.208 & 0.027 & 5.19844 & 6.409 & 100.00 & 99.22 & 194.35 & 1814.3 & 14.6 \\
\hline $\begin{array}{l}\text { FP403 } \\
\text { amphibole }\end{array}$ & \multicolumn{9}{|c|}{$J=0.008921$} \\
\hline 1 & 418.676 & 1.078 & 1.97863 & 462.2070 & 0.13 & 67.41 & 282.59 & 2270.9 & 97.4 \\
\hline 2 & 207.920 & 0.270 & 3.45192 & 73.9160 & 0.29 & 89.61 & 186.74 & 1769.0 & 54.8 \\
\hline 3 & 151.189 & 0.112 & 2.31613 & 21.3450 & 0.54 & 95.93 & 145.26 & 1499.4 & 52.8 \\
\hline 4 & 180.155 & 0.283 & 2.46759 & 29.4280 & 0.93 & 95.27 & 171.90 & 1677.1 & 27.4 \\
\hline 5 & 197.567 & 0.378 & 2.00671 & 2.4390 & 4.64 & 99.70 & 197.24 & 1831.3 & 5.1 \\
\hline 6 & 189.551 & 0.368 & 1.88536 & 0.000 & 5.30 & 99.99 & 189.91 & 1788.0 & 23.3 \\
\hline 7 & 191.198 & 0.358 & 1.88943 & 0.0020 & 23.52 & 99.99 & 191.56 & 1797.8 & 3.4 \\
\hline 8 & 192.826 & 0.347 & 1.93332 & 0.9660 & 31.12 & 99.92 & 192.91 & 1805.9 & 8.9 \\
\hline 9 & 191.075 & 0.370 & 2.04858 & 0.1870 & 52.56 & 99.99 & 191.41 & 1797.0 & 3.9 \\
\hline 10 & 194.023 & 0.357 & 1.96647 & 7.0270 & 55.33 & 99.00 & 192.32 & 1802.4 & 8.0 \\
\hline 11 & 194.493 & 0.369 & 2.18707 & 1.9960 & 68.72 & 99.77 & 194.33 & 1814.2 & 5.7 \\
\hline 12 & 193.594 & 0.364 & 2.32707 & 1.2360 & 78.84 & 99.89 & .43 .8 & 1810.4 & 3.8 \\
\hline 13 & 190.326 & 0.333 & 2.06994 & 0.0 & 81.27 & 92.9 & 190.72 & 1792.9 & 10.1 \\
\hline 14 & 196.958 & 0.345 & 2.14268 & 1.9220 & 100.00 & 99.79 & 196.81 & 1828.8 & 3.2 \\
\hline
\end{tabular}

